\title{
Polymer Cold-Flow Improvers for Biodiesel
}

\author{
Ilya Nifant'ev 1,2,*(D) and Pavel Ivchenko ${ }^{1,2}$ (D) \\ 1 A.V. Topchiev Institute of Petrochemical Synthesis RAS, 29 Leninsky Pr., 119991 Moscow, Russia; \\ phpasha1@yandex.ru or inpv@org.chem.msu.ru \\ 2 Chemistry Department, M.V. Lomonosov Moscow State University, 1 Leninskie Gory Str., Building 3, \\ 119991 Moscow, Russia \\ * Correspondence: ilnif@yahoo.com or inif@org.chem.msu.ru; Tel.: +7-495-939-4098
}

Citation: Nifant'ev, I.; Ivchenko, P. Polymer Cold-Flow Improvers for Biodiesel. Polymers 2021, 13, 1580. https://doi.org/10.3390/ polym13101580

Academic Editors: Dong Jin Yoo and Mohanraj Vinothkannan

Received: 21 April 2021

Accepted: 13 May 2021

Published: 14 May 2021

Publisher's Note: MDPI stays neutral with regard to jurisdictional claims in published maps and institutional affiliations.

Copyright: (c) 2021 by the authors. Licensee MDPI, Basel, Switzerland. This article is an open access article distributed under the terms and conditions of the Creative Commons Attribution (CC BY) license (https:// creativecommons.org/licenses/by/ $4.0 /)$.

\begin{abstract}
In recent decades, biodiesel has been explored as a prospective comparable fuel to petroleum diesel for compression ignition engines. However, several drawbacks have limited the wide application of biodiesel as motor fuel, and the poor cold-flow property is one of the major problems. This problem is compounded by the diversity of the biodiesel characteristics arising from a variety of chemical compositions of biodiesel from different sources. Among the methods investigated to improve the cold-flow properties of biodiesel, the use of additives seems highly promising. Despite the significant number of publications, the potential of this method is still far from having been completely discovered or exploited. In the present review, we briefly describe the sources, chemical composition, and physico-chemical characteristics of the main types of biodiesel. Next, we discuss the examples of the use of different polymer additives for the improvement of the cold-flow characteristics of biodiesel and biodiesel/petroleum diesel blends. Additionally, we tried to assess the prospects of the polymer additives to enhance biodiesel performance. The main conclusion of this survey is that innovative and high-efficiency cold-flow improvers for biodiesel should be further developed.
\end{abstract}

Keywords: biodiesel; cloud point; cold-flow property; depressants; dispersants; esters; fatty acids; pour point

\section{Introduction}

The concept of progressive and sustainable development stimulated the search for strategies for producing fuels, lubricants and chemicals from renewable sources. Biofuels, derived from plant biomass, are the only sustainable source of liquid fuels [1,2]. The global biofuel consumption in the road transport sector demonstrates stable growth (Figure 1) [3]. It is expected that the share of biofuels will amount to $\sim 5 \%$ of liquid fuels for the transport industry by 2040 [4].

Biodiesel (BD) is a mixture of fatty acid (FA) alkyl esters (mainly methyl esters) obtained from oils and fats by transesterification (Figure 2). The worldwide biodiesel production in 2019 was 48 billion L [5]. The use of BD as fuel presents some advantages such as reduced particulate matter, unburnt hydrocarbon, carbon monoxide emissions, higher cetane number and better lubricity in comparison with petroleum diesel. However, the use of biodiesel is affected by its poor cold-flow properties (CFP) [6]. The impacts of cold temperatures on biodiesel in fuel systems are generally limited to start-up and operability problems that may arise when the engine and fuel system are shut down overnight. These impacts would then result from gelling or solidification in the fuel that can restrict or plug the flow of fuel in the fuel system [7].

The studies of BD are still extremely significant (Figure 3). Many reviews focus on the synthesis, purification, upgrading, properties and applications of BD [8-31]. The problem of improving the CFP of BD was also discussed in a number of reviews [6,32-43]. 


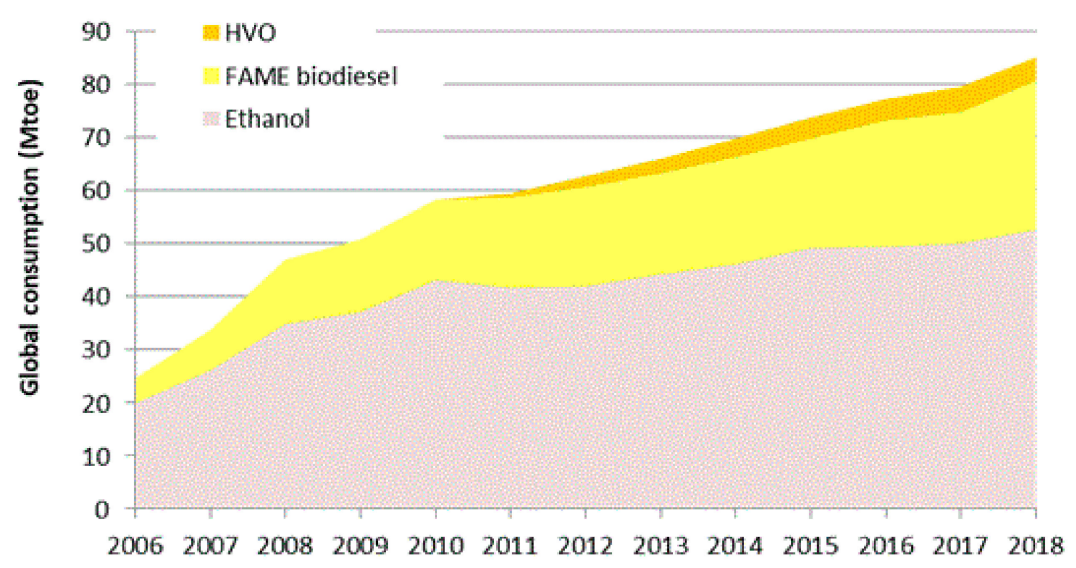

Figure 1. Evolution of global biofuel consumption in the road transport sector (FAME-Fatty Acid Methyl Esters, biodiesel; HVO-Hydrotreated Vegetable Oils) [3].<smiles>[R]C(=O)OCC(COC([R])=O)OC([R])=O</smiles><smiles></smiles>

Figure 2. The synthesis of BD by transesterification of glycerides (oils and fats).

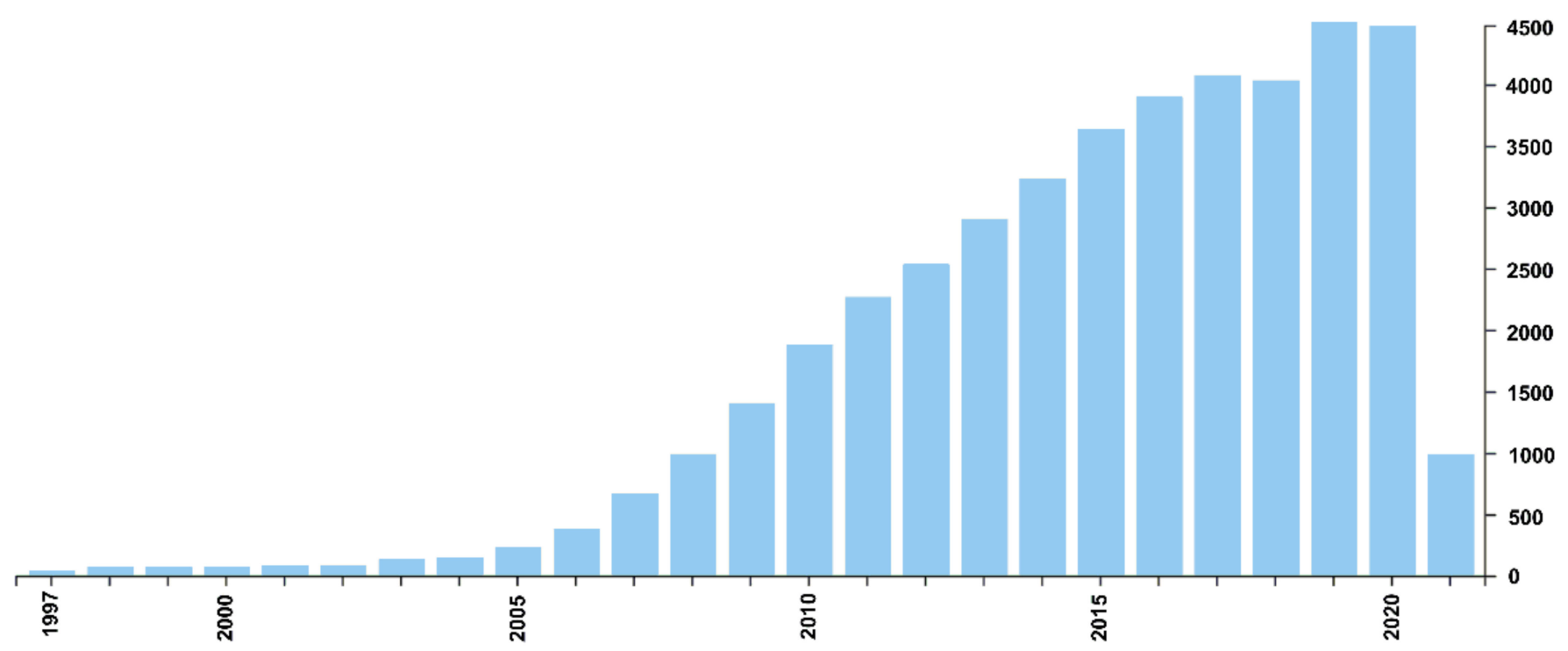

Figure 3. Annual numbers of scientific articles on the topic of "biodiesel." Web of Science data (Thomson-Reuters, 15 April 2021).

There are several ways in which the problem of poor CFP of BD can be solved. CFP of BD can be improved significantly using pre-treatment of the BD ("winterization") [32], 
by mixing with petroleum diesel or blending with fatty acid esters with good CFP, and by using of the additives, cold-flow improvers (CFIs) [6,33,35,37-43].

Low molecular weight (MW) CFIs have been well-represented in the literature, and relatively high efficiency was demonstrated by ethanol as diluent [44], hydroxyacetone, solketal, glycerol formal [45], ozonized vegetable oil [46], triacetin [47,48], dimethyl azelate [48], branched esters of FA [49,50], monoglycerides as emulsifiers [51], mannosylerythritol lipid-A [52], branched diesters [53,54] and other compounds [6,32-43]. However, it is difficult to find a balance between the effect of the additives and the result of blending: actually, appreciable percentages of low MW additives were acting as a component of binary/ternary mixtures, which naturally have lower crystallization points $[44,55,56]$.

On the basis of polymer science, high-MW CFIs are of greater interest to developing BD-based fuel recipes suitable for use in countries with colder climates. This approach had been effective in improving the CFP of petroleum diesel and oil products [57-59]. In the present review, we describe the key characteristics of the BD based on compositions of the raw materials, discuss the CFP of $\mathrm{BD}$ from different sources, and analyze the data on the use of polymers to improve the CFP of $\mathrm{BD}$ and $\mathrm{BD}$ blends.

\section{Sources, Synthesis and Chemical Composition of BD}

\subsection{Oils, as Raw Material for the Production of BD}

$\mathrm{BD}$ is produced using oil from various sources, including edible vegetable oils, nonedible oils, waste oils and fats. Since the sources of the feedstocks for BD production are based on regional availabilities, the compositions of the fatty acid alkyl esters also vary due to the difference in the compositions of the saturated and unsaturated fatty acids (Figure 4) in corresponding triglycerides. In Table 1, we presented the data on the composition of glycerides that form oils used as BD feedstocks [16,60].

Conventionally, BD is classified based on their feedstock and production technologies into three different generations, namely, produced from edible oils (1st generation), from non-edible oils (2nd generation), and from other sources such as algae oil, waste cooking oil, and fats (3rd generation) [28]. Hajjari et al. [23] proposed a wider classification of the BD feedstocks, which is based on the sustainability aspects (Figure 5). Taking into consideration that the limiting issue in BD production is feedstock supply, they evaluated the prospects and economic feasibility of the various options of BD manufacturing and noted that the driving force for the migration from food-based biodiesel (first generation) to the next generations had been the fuel vs. food/feed competition over crops, limited arable land and freshwater [61]. In particular, the production of $\mathrm{BD}$ from algae is considered to be prospective and economically beneficial [18], and the high relevance of this area of research had been confirmed by a number of actual reviews [62-68].

To date, more than $95 \%$ of biodiesel is produced from edible vegetable oils [69]. However, it can be expected that 2nd and following generations of BD will become more meaningful in the near future-therefore, the study of the CFP of the corresponding BDs and the development of efficient CFIs for novel BD recipes will be performed inevitably. 
<smiles>CCCCCC(=O)O</smiles>

Caproic acid<smiles>CCCCCCCC(=O)O</smiles>

Caprylic acid<smiles>CCCCCCCCCC(=O)O</smiles>

Capric acid<smiles>CCCCCCCCCCCC(=O)O</smiles>

Lauric acid<smiles>CCCCCCCCCCCCCC(=O)O</smiles>

Myristic acid<smiles>CCCCCCCCCCCCCCCC(=O)O</smiles>

Palmitic acid

18:0<smiles>CCCCCCCCCCCCCCCCCC(=O)O</smiles>

\section{Stearic acid}

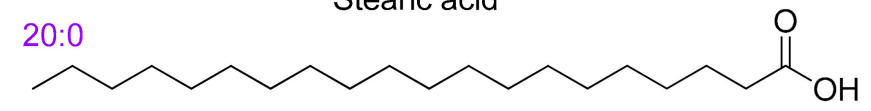

22:0

Arachidic acid<smiles>CCCCCCCCCCCCCCCCCCCCCC(=O)O</smiles>

Behenic acid<smiles>CCCCCCCC/C=C\CCCCCCCC(=O)O</smiles><smiles>CCCC/C=C\C/C=C\CCCCCCCC(=O)O</smiles>

$18: 3 \Delta 9 \mathrm{C} \Delta 12 \mathrm{C} \Delta 15 \mathrm{C}$<smiles>CC/C=C\C/C=C\C/C=C\CCCCCCCC(=O)O</smiles>

\section{$20: 1 \Delta 9 C$}

Linolenic acid

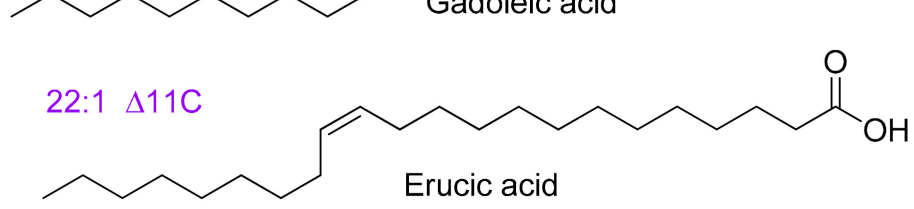

$20: 5 \Delta 5 C \Delta 8 C \Delta 11 C \Delta 14 C \Delta 17 C$<smiles>CC/C=C\C/C=C\C/C=C\C/C=C\C/C=C\CCCC(=O)O</smiles>

Timnodonic acid

Figure 4. Molecular formula and lipid codes of the main fatty acids (FAs) in oils and fats used in the synthesis of BD.

Table 1. FA composition of different oils [16].

\begin{tabular}{|c|c|c|c|c|c|c|c|c|c|c|c|c|c|c|}
\hline \multicolumn{2}{|c|}{ Acid Name } & \multicolumn{13}{|c|}{ Percent Composition in Oil ${ }^{1}$} \\
\hline Common & Lipid & RS & CA & CR & SU & SB & $\mathbf{P}$ & PK & OL & PN & $\mathrm{CO}$ & SA & TL & $\underset{2}{\mathrm{AlC}}$ \\
\hline Caproic & $6: 0$ & - & - & - & - & - & - & $\operatorname{tr}-1.5$ & - & - & $0-0.8$ & - & - & - \\
\hline Caprylic & $8: 0$ & - & - & - & - & - & $\operatorname{tr}$ & $3-5$ & - & - & $5-9$ & - & - & - \\
\hline Capric & $10: 0$ & - & - & - & - & $\operatorname{tr}$ & $\operatorname{tr}$ & $3-7$ & - & - & $6-10$ & - & - & - \\
\hline Lauric & $12: 0$ & - & - & - & - & $\operatorname{tr}$ & $\operatorname{tr}$ & $40-52$ & - & - & $44-52$ & - & $\operatorname{tr}-0.2$ & - \\
\hline Myristic & $14: 0$ & - & - & $\operatorname{tr}-1.7$ & - & $\operatorname{tr}$ & $0.5-6$ & $14-18$ & $0.1-1.2$ & $\operatorname{tr}-1$ & $13-19$ & $\operatorname{tr}$ & $2-8$ & 2.0 \\
\hline Palmitic & $16: 0$ & $1-3$ & 4 & $8-12$ & $3-6$ & $7-11$ & $32-45$ & 7-9 & $7-16$ & $6-9$ & 8-11 & $3-6$ & $24-37$ & 19.6 \\
\hline Stearic & $18: 0$ & $0.4-3.5$ & 2 & $2-5$ & $1-3$ & $2-6$ & $2-7$ & $1-3$ & $1-3$ & $3-6$ & $1-3$ & $1-4$ & $14-29$ & 3.3 \\
\hline Arachidic & $20: 0$ & $0.5-2.4$ & - & $\operatorname{tr}$ & $0.6-4$ & $0.3-3$ & $\operatorname{tr}$ & $\operatorname{tr}-1$ & $0.1-0.3$ & $2-4$ & $0-0.4$ & $\operatorname{tr}-0.2$ & $\operatorname{tr}-1.2$ & - \\
\hline Behenic & $22: 0$ & $0.6-2.1$ & - & $\operatorname{tr}$ & $\operatorname{tr}-0.8$ & $\operatorname{tr}$ & - & - & - & $1-3$ & - & - & - & - \\
\hline Palmitoleic & $16: 1$ & $0.2-3$ & - & $0.2-1.6$ & $\operatorname{tr}$ & $\operatorname{tr}$ & $0.8-1.8$ & $\operatorname{tr}-1$ & $\operatorname{tr}$ & $\operatorname{tr}-1.7$ & $0-1$ & - & $1.9-2.7$ & 0.8 \\
\hline Oleic & $18: 1$ & $12-24$ & 61 & $19-49$ & $14-43$ & $15-33$ & $38-52$ & $11-19$ & $65-85$ & $53-71$ & $5-8$ & $13-21$ & $40-50$ & 5.7 \\
\hline Gadoleic & $20: 1$ & $4-12$ & - & - & - & - & - & - & - & - & - & - & - & 0.1 \\
\hline Erucic & $22: 1$ & $40-55$ & $\operatorname{tr}$ & - & - & - & - & - & - & - & - & - & - & - \\
\hline Linoleic & $18: 2$ & $12-16$ & 21 & $34-62$ & $44-75$ & $43-56$ & $5-11$ & $0.5-2$ & $4-15$ & $13-27$ & $\operatorname{tr}-2.5$ & $73-79$ & $1-5$ & 11.8 \\
\hline Linolenic & $18: 3$ & $7-10$ & $9-12$ & $\operatorname{tr}$ & $\operatorname{tr}$ & 5-11 & $\operatorname{tr}$ & - & $\operatorname{tr}-1$ & $\operatorname{tr}$ & - & $\operatorname{tr}$ & - & 22.3 \\
\hline Timnodonic & $20: 5$ & - & - & - & - & - & - & - & - & - & - & - & - & 1.3 \\
\hline
\end{tabular}

${ }^{1}$ Oils: RS-rapeseed, CA—canola, CR-corn, SU-sunflower, SB-soybean, P-palm, PK-palm kernel, OL-olive, PN-peanut, $\mathrm{CO}$-coconut, SA—safflower, TL—tallow and AlC—algae Chlorella. ${ }^{2}$ Contains $3.6 \% 16: 2$ and 12.0\% $16: 3$ acids. 

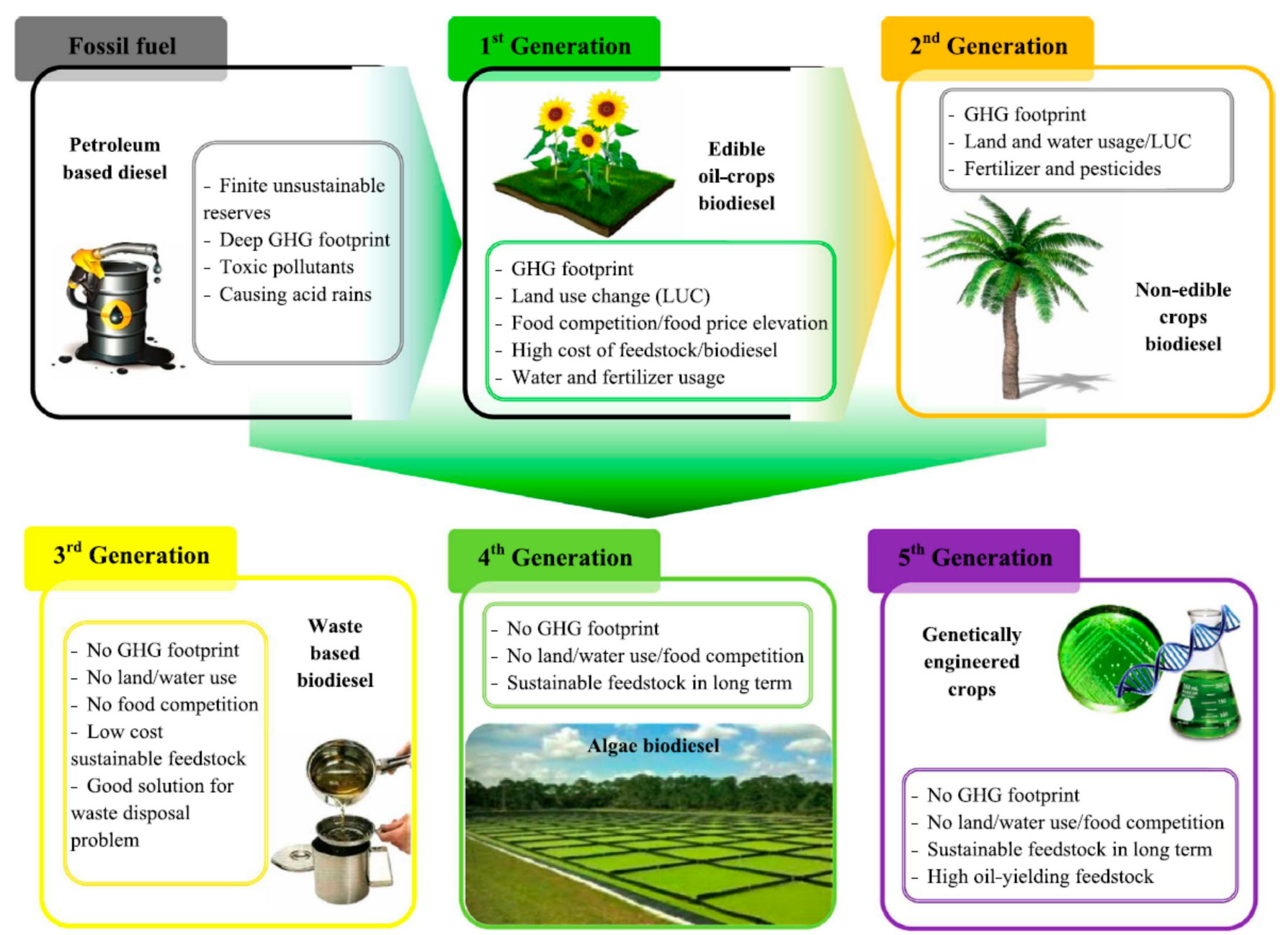

Figure 5. New classification of BD feedstocks based on the sustainability issue. Reprinted with permission from [23]. Copyright (2017) Elsevier B.V.

\subsection{Synthesis of $B D$}

The basic methods of the synthesis of biodiesel have been reviewed in a number of publications $[8-10,15,19,24,70,71]$. Transesterification of triglycerides with a formation of FA methyl esters (FAMEs) and more expensive and less-used ethyl and isopropyl esters (Figure 2) can be catalyzed by acids and bases. Alkaline catalysts are usually more than three orders of magnitude active in comparison with mineral acids and are commonly applied in industry. Sodium methoxide is one of the most active catalysts for BD production [1]. However, the limited miscibility of triglycerides with methanol hampers the first stage of transesterification in the catalytic synthesis of FAMEs. In addition, high yields of FAMEs can be achieved only if the feedstocks of high purity (the absence of water and hydroxy group containing admixtures) have been used-for example, first-generation edible oils, which brings us back to the problem of fuel vs. food/feed competition.

An efficient method of the synthesis of FAMEs is Supercritical Methanol (SM) processing [70]. Already the first study of Saka and Kusdiana [72] demonstrated the high efficiency of this approach, which was reflected in low reaction time and higher yields of the methyl esters. Further studies of transesterification using supercritical methanol and ethanol confirmed the high efficiency of this approach [73]. Alternative approaches to transesterification of the BD feedstocks use heterogeneous [74,75] and enzymatic [76] catalysts. The rational choice of the catalyst and method of production depends on the type of feedstock. 


\subsection{Chemical Composition of $B D$}

Obviously, the chemical composition of the $\mathrm{BD}$ is determined by the composition of the feedstocks. The above Table 1 has shown in brief the composition of several major oils in terms of the ratio of FAs in triglycerides. In addition to triglycerides of FAs, BD feedstocks contain components that also have an impact on the CFP of the BD. To date, hundreds of $\mathrm{BD}$ compositions obtained from different sources have been analyzed. The chemical analysis of BD is based on gas chromatography (GC) [77-81], GC in combination with mass spectrometry (GC/MS) [80] and NMR spectroscopy [82]. ${ }^{1} \mathrm{H}$ NMR spectra [82] (Figure 6) and well-programmed GC/FID [80] allow determining a contence of saturated and poly(unsaturated) FAs in BD samples.

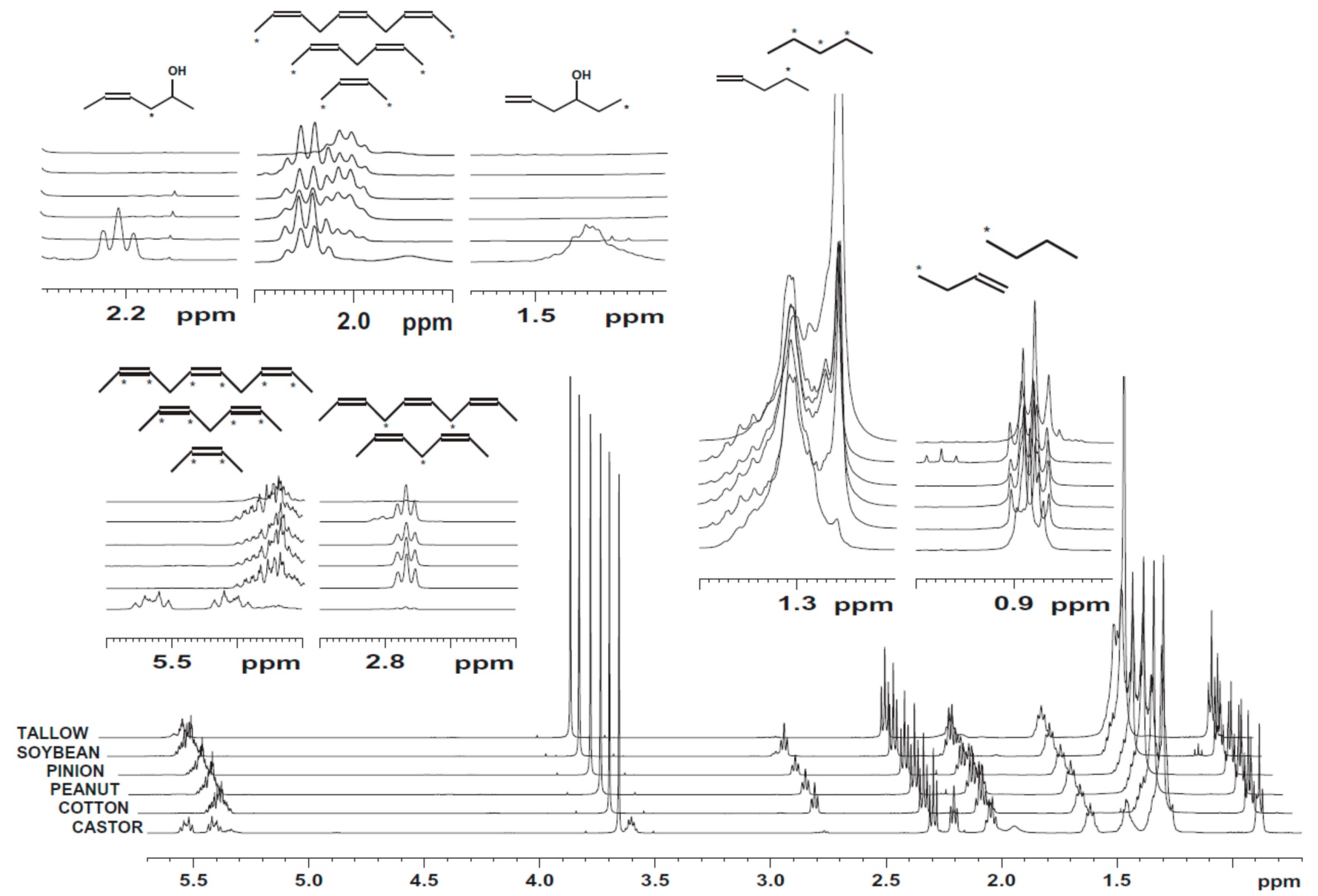

Figure 6. ${ }^{1} \mathrm{H}$ NMR spectra for pure biodiesel samples from different sources. Reprinted with permission from [82]. Copyright (2012) Elsevier B.V.

\section{Cold-Flow Properties of BD}

\subsection{Cold-Flow Properties: Standards and Analysis}

The cold-flow properties define the flow behavior of BD at low temperatures. International standards consider three main characteristics, namely, cloud point, pour point and cold filter plugging point. The cloud point $(\mathrm{CP})$ is the temperature of the oil liquid sample when the smallest observable solid particles first occur upon cooling due to crystallization of the alkyl ester with the highest melting point [6]. CP can be measured according to ASTM standards D2500, D5771, D5772, D5773, D6751, D7397 and D7467 [37,83]. CP is related to the possibility of injectors and filters obstruction. The pour point (PP) is the lowest temperature where motion can be detected when the sample is tilted. PP can be measured according to ASTM standards D97, D5949, D5950, D5985, D6749 and D6982 [37]. 
The cold filter plugging point (CFPP), determined in accordance with ASTM D6371, is the lowest temperature at which a given volume of fuel passes through a standardized wire mesh filter in a specified time. These three characteristics are determined using standard equipment with a significant margin of error.

At the same time, some more knowledge-intensive methods are essential for the study of BD blends and formulations and the investigation of the effect of cold-flow improvers. These methods are differential scanning calorimetry (DSC) or modulated temperature DSC (MT-DSC) [84,85], light scattering [86] and precision rheometry $[84,87,88]$. The use of these methods allows determining the temperatures of the phase transitions in BD samples with high accuracy.

\subsection{Cold Flow Properties of BDs: FA Composition}

The use of biodiesel is affected by poor cold-flow properties, namely CP, PP and CFPP [6]. These characteristics are essentially concerned with the basic composition and ratio of the fatty acids alkyl esters obtained from different feedstocks. The melting points of the main components of BD were comprehensively studied more than 10 years ago by Knothe et al. $[15,89]$. The saturated esters have a higher melting point than that of unsaturated esters with the same number of carbon atoms (Table 2); therefore, a higher amount of saturated FA esters in biodiesel fuels can lead to higher CP, PP and CFPP values [90]. A comprehensive study of the CFPP of more than three hundred BD blends was carried out by Yuan et al. [91]. The low-temperature phase behavior of BD components may be complicated by polymorphism and pressure-induced crystallization of FAMEs. To date, very little research has been done on this problem; for example, Liu et al. detected and characterized five crystal modifications of methyl stearate with pressure-dependent stability [92,93], whereas Prathapa et al. studied the crystal package of C8-C13 saturated FAMEs systematically [94].

Table 2. Melting points of FAMEs [15,89].

\begin{tabular}{cccccc}
\hline & \multicolumn{2}{c}{ M. P. $\left({ }^{\circ} \mathbf{C}\right)$} & \multicolumn{2}{c}{ M. P. $\left({ }^{\circ} \mathbf{C}\right)$} \\
\hline Saturated Esters & Me & Et & Unsaturated Esters & Me & Et \\
\hline $8: 0$ & -37.4 & -44.7 & $16: 1 \Delta 9 \mathrm{c}$ & -34.1 & -36.7 \\
$10: 0$ & -13.5 & -20.4 & $18: 1 \Delta 6 \mathrm{c}$ & -1.0 & -7.7 \\
$12: 0$ & 4.3 & -1.8 & $18: 1 \Delta 9 \mathrm{c}$ & -20.2 & -20.3 \\
$14: 0$ & 18.1 & 12.5 & $18: 1 \Delta 9 \mathrm{t}$ & 9.9 & 4.2 \\
$16: 0$ & 28.5 & 23.2 & $18: 1 \Delta 11 \mathrm{c}$ & -24.3 & -36.5 \\
$18: 0$ & 37.7 & 32.9 & $18: 2 \Delta 9 \mathrm{c}, \Delta 12 \mathrm{c}$ & -43.1 & -56.7 \\
$20: 0$ & 46.4 & 41.3 & $18: 3 \Delta 9 \mathrm{c}, \Delta 12 \mathrm{c}, \Delta 15 \mathrm{c}$ & -52 & -61.7 \\
$22: 0$ & 53.2 & 48.6 & $20: 1 \Delta 11 \mathrm{c}$ & -7.8 & -8.8 \\
$24: 0$ & 58.6 & 55.9 & $22: 1 \Delta 13 \mathrm{c}$ & -3.1 & -10.5 \\
\hline
\end{tabular}

\subsection{Microimpurities}

In addition to the main components, fatty acid esters, BD can contain microimpurities also affecting the CFP, monoacylglycerols (MAG, formed as intermediates in the transesterification) and steryl glucosides [95]. As was demonstrated by Chupka et al., an increase of $0.01 \mathrm{wt} \%$ saturated MAG in a biodiesel blend results in an increase of $\mathrm{CP}$ by $4{ }^{\circ} \mathrm{C}$ [86]. The high melting points of saturated monoacylglycerols (melting points of monopalmitin and monostearin exceed $70{ }^{\circ} \mathrm{C}$ ), which can precipitate in different crystal forms [96], and free steryl glucosides (M. P. $>240^{\circ} \mathrm{C}$ ) cause these materials to crystallize from biodiesel more readily than the esters of fatty acids [34].

\section{Polymer Additives for BD}

Mixing suitable additives to improve the low-temperature characteristics of biodiesel is one of the more effective methodologies. Such additives are known as cold-flow improvers (CFIs) $[97,98]$. CFIs modify the agglomerative nature of the crystals at low tem- 
peratures, as well as transform the crystal shapes from typical plate to needle-like. These smaller crystals do not face viscous resistance while flowing through the fuel filter and injector [99]. Generally, the pour point depressant (PPD) type of CFIs are most effective for biodiesel [100].

The long history of the use of PPDs for the improvement of the cold-flow characteristics of crude oils and petroleum products resulted in the development of various polymeric additives [57-59,101]. The use of the polymeric PPDs to upgrade CFP of BD was reported in a number of research papers [97,98,100,102-108], patents [109-111] and raised in recent reviews $[33,35,38-41,54,112]$. However, the published data are often fragmentary and sometimes contradictory. In this Section, which in fact is the subject of our review, we tried to summarize and analyze the published data concerning the effect of the polymers of different types on CFP of BDs, obtained from different feedstocks. It is very unfortunate that a number of publications did not include the data concerning the composition and molecular weight characteristics of polymeric PPDs under study as opposed to PPDs synthesized and studied in the improvement of the CFP of crude oils and petroleum-based products.

\subsection{Polyolefins}

Polyolefin CFIs, based on polyethylene-poly(ethylene-alt-propylene) [113-116], ethylene/1-butene or ethylene/higher $\alpha$-olefin copolymers [117-120], demonstrated marked efficiency in the improvement of the CFP of petroleum-based products. However, similar polymers did not show a substantial effect when used in BDs. For example, a number of industrial polyolefin depressants were tested in $0.1 \mathrm{wt} \%$ concentrations by Nie and Cao as CFIs for waste cooking oil BD [108]. In all cases, polyolefin PPDs demonstrated moderate efficiency, the lowering of PP and CFPP was $2-3{ }^{\circ} \mathrm{C}$. Note that comonomer composition and ratios, as well as molecular weight characteristics of polyolefin PPDs, used in [108], have not been reported in detail. Commercial polyolefin depressant T803 (Antai Chemicals Co. Ltd., Shanghai, China) was tested as $0.02-0.08 \mathrm{wt} \%$ solutions in waste cooking oil BD [98], the lowering of $\mathrm{CP}$ and CFPP was only $1{ }^{\circ} \mathrm{C}$, the maximum impact on $\mathrm{PP}$ was $-3{ }^{\circ} \mathrm{C}$ when $0.04 \mathrm{wt} \%$ of $\mathrm{T} 803$ was added.

Sern et al. reported no effect of poly(1-decene) for palm oil BD up to $2 \mathrm{wt} \%$ concentrations of the additive [105].

\subsection{Ethylene/Vinyl Acetate Copolymers}

Copolymers of ethylene and vinyl acetate (EVA copolymers) represent bulk products that are manufactured using high-pressure free-radical copolymerization of low-cost comonomers, ethylene and vinyl acetate (Scheme 1) and represent the most widely used PPDs for petroleum-based diesel fuel [121-123].

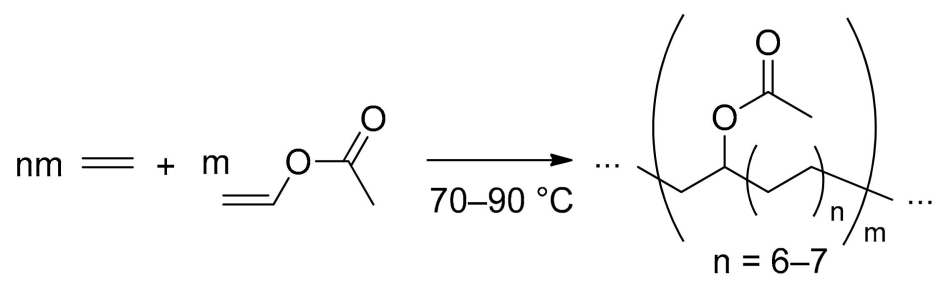

Scheme 1. The synthesis of ethylene/vinyl acetate copolymers (EVA).

The effectiveness of EVA copolymers very much depends on the comonomers ratio, the optimum ratio of ethylene and vinyl acetate is 6-7 for copolymers used for CFIs of petroleum diesel [124]. The mechanism of the effect of EVA copolymers on the paraffin deposition in petroleum diesel is attributable to the coordination of the oleophilic fragment of the EVA copolymer macromolecule on the surface of the paraffin crystals resulting in the formation of smaller-scale crystals [125]. Moreover, the same mechanism is applicable for BDs (see below). 
Wang et al. reported that EVA copolymers have no effect on $\mathrm{CP}$ of waste cooking oil $\mathrm{BD}$ at concentrations of $0.02-0.08 \mathrm{wt} \%$, CFPP was reduced by $2{ }^{\circ} \mathrm{C}$; however, the lowering of PP was more visible, up to $6{ }^{\circ} \mathrm{C}$ [98]. For soybean BD, the presence of EVA copolymer in $0.01 \mathrm{wt} \%$ concentration resulted in PP lowering by $2{ }^{\circ} \mathrm{C}$ [106]. Gao et al. studied CFP of the waste cooking oil BD at EVA copolymer concentrations of $0.02-0.08 \mathrm{wt} \%$ and detected only a marginal effect (no change of $\mathrm{CP}$, the lowering of PP by $3{ }^{\circ} \mathrm{C}$ ) [103]. For canolabased methyl esters, the addition of $1 \mathrm{wt} \%$ EVA copolymers resulted in lowering of PP by $11{ }^{\circ} \mathrm{C}$, but $\mathrm{CP}$ remains unchanged [100]. The addition of $0.3 \mathrm{wt} \%$ of the commercial additive Keroflux (BASF), ethylene/vinyl acetate/acrylate copolymer (86, 16 and $3 \mathrm{~mol} \%$, respectively, $M_{\mathrm{n}}=4.14 \mathrm{kDa}$ ) to the blend of rapeseed and soybean oil methyl esters reduced $\mathrm{CP}$ by $2{ }^{\circ} \mathrm{C}$ and CFPP by $9^{\circ} \mathrm{C}$ [126].

Hamada et al. evaluated polyglycerol esters of fatty acids (PGE) and EVA copolymer as additives to improve the CFP of palm oil-based BD ( $46 \%$ of saturated FAMEs, $\mathrm{CP}=15^{\circ} \mathrm{C}, \mathrm{PP}=14^{\circ} \mathrm{C}$ ) [127]. They found that these additives led to the formation of considerably small and fine-dispersed crystals, but such an effect was not observed when EVA copolymer was used alone. The synergy in the simultaneous addition of PGE and EVA copolymer was convincingly demonstrated by using Solid Fat Content (SFC) NMR analysis of the direct ratio between the solid and liquid parts of the sample (Figure 7). Figure 7a clearly illustrates the low efficiency of the EVA copolymer; however, an addition of PGE significantly decreased the SFC values. The evolution of SFC values over time under isothermal conditions (Figure $7 \mathrm{~b}$ ) showed that the simultaneous addition of $1 \mathrm{wt} \%$ EVA copolymer and $1 \mathrm{wt} \%$ PGE results in a dramatic decrease in SFC values.

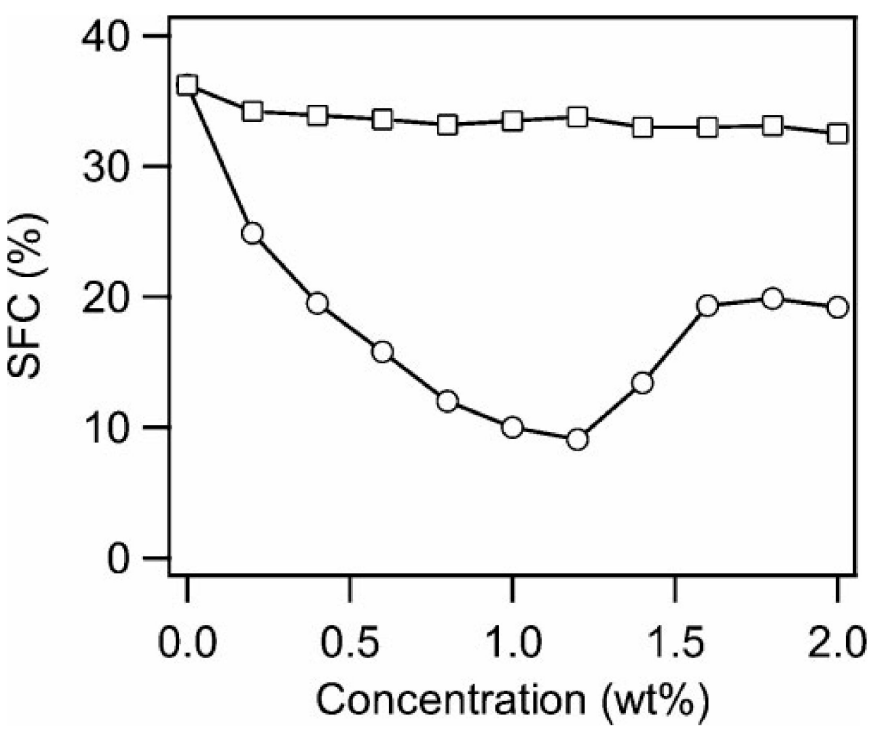

(a)

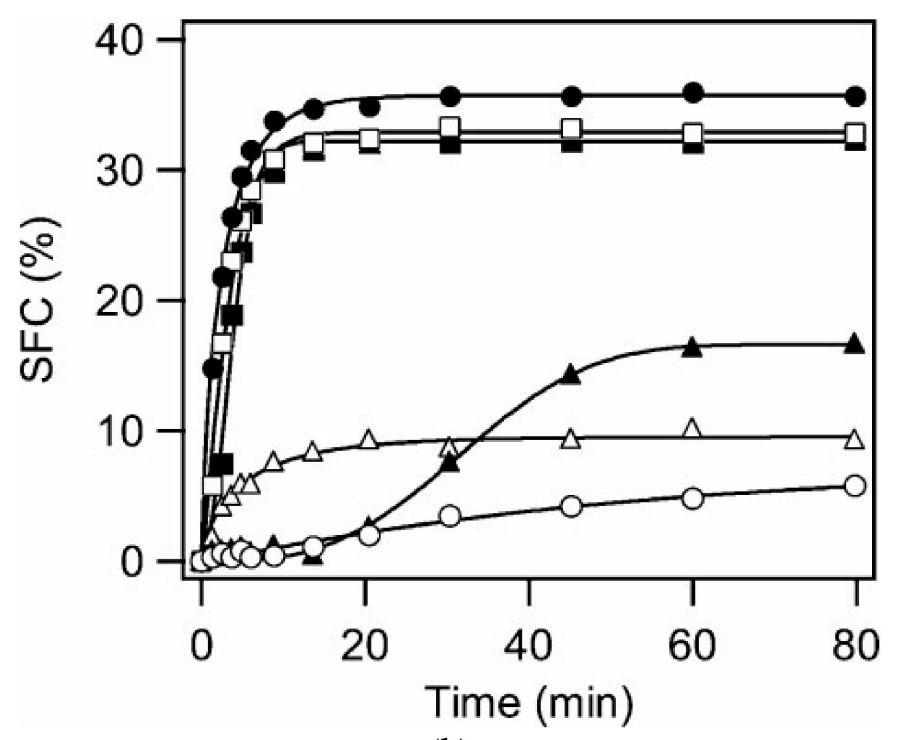

(b)

Figure 7. (a) Solid Fat Content (SFC) NMR analysis for PGE and EVA additives ( $2 \mathrm{wt} \%$, open circles and open squares, respectively) taken at $9{ }^{\circ} \mathrm{C}$ after $60 \mathrm{~min}$; (b) Time variation of SFC with and without additives measured at $9{ }^{\circ} \mathrm{C}$. Pure PFME (closed circles), $1 \mathrm{wt} \%$ EVA (open squares), $2 \mathrm{wt} \%$ EVA (closed squares), $1 \mathrm{wt} \%$ PGE (open triangles), $2 \mathrm{wt} \%$ PGE (closed triangles) and $1 \mathrm{wt} \%$ PGE $+1 \mathrm{wt} \%$ EVA (open circles). Reprinted with permission from [127]. Copyright (2010) Wiley-VCH Verlag $\mathrm{GmbH} \& \mathrm{Co}$.

Drastic changes in crystal morphology were noticed by Hamada et al. [127] using polarized light microscopy. Figure 8 shows the crystals observed at the crystallization temperature $T_{\mathrm{C}}$ when the sample was slowly cooled from $25^{\circ} \mathrm{C}$ to $6{ }^{\circ} \mathrm{C}$. Large bulky crystals were observed in the absence of additives at $13{ }^{\circ} \mathrm{C}\left(T_{\mathrm{C}}\right.$ of pure BD, Figure $\left.8 \mathrm{~A}\right)$. In the presence of $2 \mathrm{wt} \% \mathrm{PGE}$, the size of crystals was reduced to $100 \mu \mathrm{m}$, the crystallization was observed at $8{ }^{\circ} \mathrm{C}$ (Figure $8 \mathrm{~B}$ ). An addition of $2 \mathrm{wt} \%$ EVA formed crystal spherulites (Figure $8 \mathrm{C}$ ), which were composed of needle-like crystals. Finally, the simultaneous 
addition of $1 \mathrm{wt} \%$ EVA copolymer and $1 \mathrm{wt} \%$ PGE caused the formation of small crystals (Figure 8D). For the last case, CFPP was reduced by the value of $6{ }^{\circ} \mathrm{C}$.
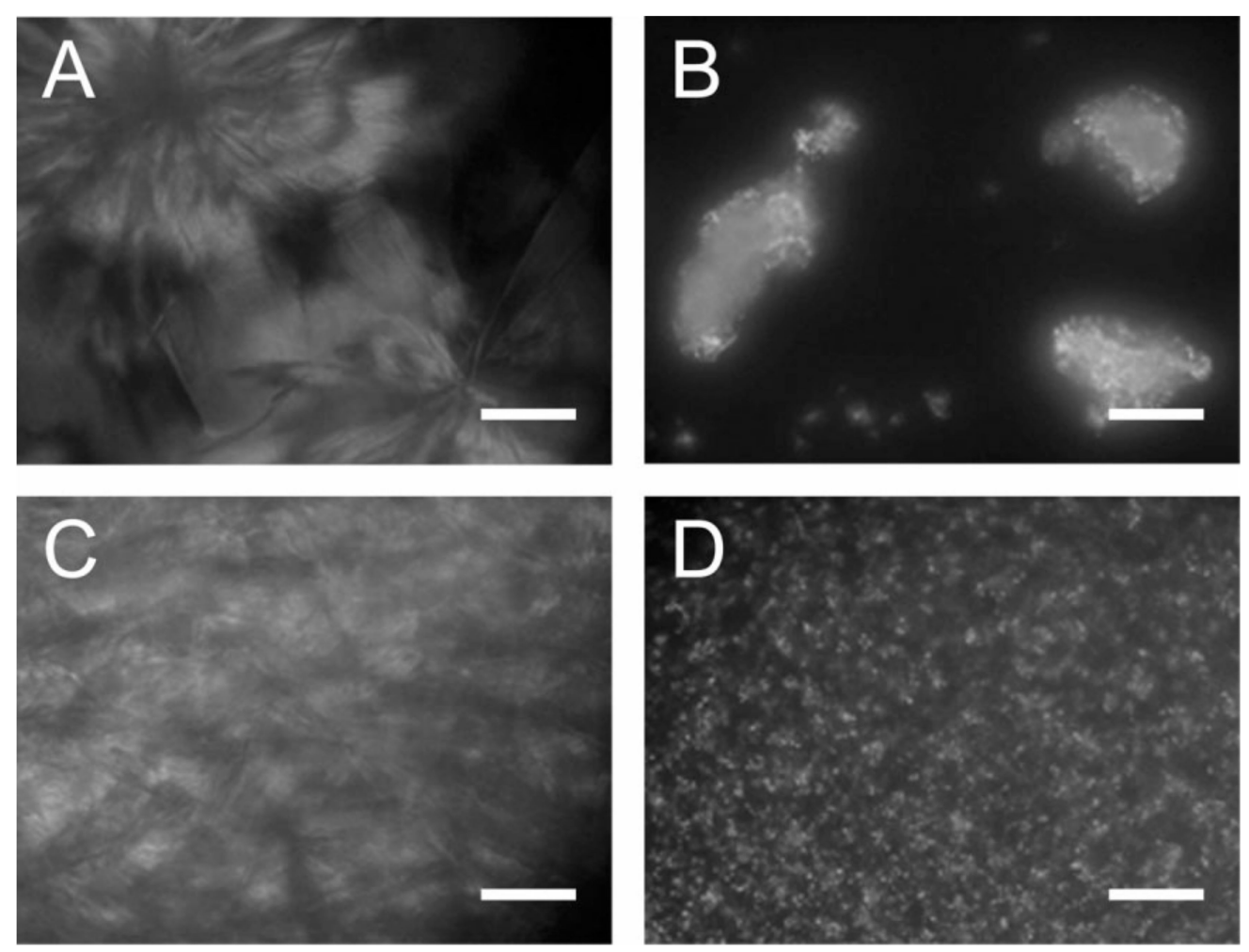

Figure 8. Optical micrographs of PFME crystals taken during the cooling process. Scale bar indicates $100 \mu \mathrm{m}$. (A) No additives, (B) $2 \mathrm{wt} \%$ PGE, (C) $2 \mathrm{wt} \%$ EVA and (D) $1 \mathrm{wt} \%$ PGE p $1 \mathrm{wt} \%$ EVA. Reprinted with permission from [127]. Copyright (2010) Wiley-VCH Verlag GmbH \& Co.

The effectiveness of EVA copolymers as pour point depressants can be substantially improved by free-radical grafting using alkyl methacrylates (Scheme 2) $[128,129]$. This reaction was used for the modification of partitional hydrolyzed EVA copolymers [130]. The effectiveness of grafted EVA copolymers was studied for mixtures with poly (methacrylates); see Section 4.5.
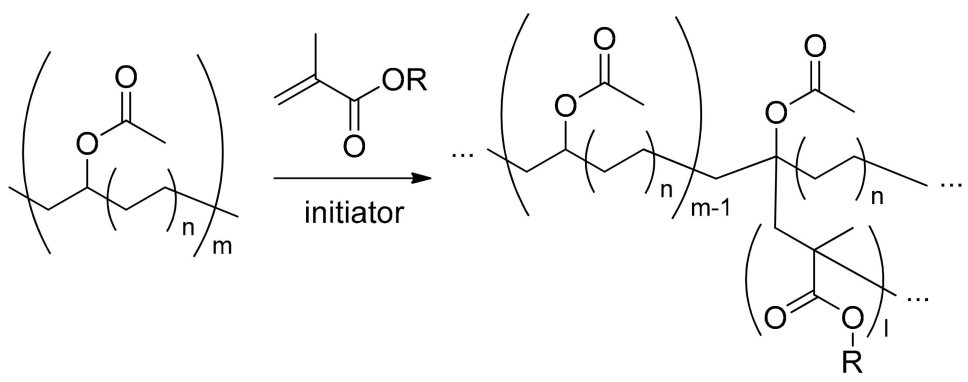

Scheme 2. The synthesis of methacrylate-grafted EVA copolymers.

\subsection{Polyacrylates and Related Copolymers}

(Co)polymers of the esters of acrylic and methacrylic acids are typically obtained by free-radical (co)polymerization (Scheme 3). The effectiveness of these CFIs in lowering of CP, PP and CFPP of the petroleum diesel is directly related to the length of the alkyl fragments in these esters, and the best results were obtained for the derivatives of $\mathrm{C}_{18}$ and higher alcohols [131,132]. 


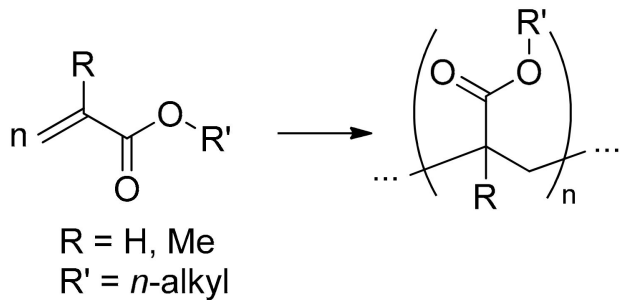

Scheme 3. The synthesis of poly((meth)acrylate)s.

The study of the impact of poly(meth)acrylates and other polymeric additives on CFP of canola oil-based methyl esters (canola BD, $6.2 \mathrm{wt} \%$ of saturated fatty acids, $\mathrm{PP}=-16^{\circ} \mathrm{C}$ ) was conducted by Chastek [100]. He demonstrated that poly(octyl methacrylate) $\left(M_{n}=100 \mathrm{kDa}\right)$ and poly (decyl methacrylate) $\left(M_{\mathrm{n}}=100 \mathrm{kDa}\right)$ are ineffective as pour point depressants for canola BD. Poly (dodecyl methacrylate) $\left(M_{n}=250 \mathrm{kDa}\right)$, on the other hand, showed a remarkable decrease of PP being used in $0.5-1 \mathrm{wt} \%$ concentrations. When $1 \mathrm{wt} \%$ was used, the PP of canola BD was $-46^{\circ} \mathrm{C}$. Poly (hexadecyl methacrylate) $\left(M_{\mathrm{n}}=200 \mathrm{kDa}\right)$ proved to be ineffective (PP was $-20^{\circ} \mathrm{C}$ for $1 \mathrm{wt} \%$ concentration).

Muniz et al. studied the effect of the addition of 0.01-0.1\% poly(alkyl acrylates) (alkyl $=n-\mathrm{C}_{8} \mathrm{H}_{17}, M_{\mathrm{n}}=4.3 \mathrm{kDa}, \bigoplus_{\mathrm{M}}=1.03 ; n-\mathrm{C}_{12} \mathrm{H}_{25}, M_{\mathrm{n}}=4.0 \mathrm{kDa}, \bigoplus_{\mathrm{M}}=1.04 ; n-\mathrm{C}_{14} \mathrm{H}_{29}$, $\left.M_{\mathrm{n}}=4.4 \mathrm{kDa}, Ð_{\mathrm{M}}=1.01\right)$ and poly(alkyl methacrylates) (alkyl $=n-\mathrm{C}_{8} \mathrm{H}_{17}, M_{\mathrm{n}}=4.0 \mathrm{kDa}$, $\left.\bigoplus_{\mathrm{M}}=1.03 ; n-\mathrm{C}_{14} \mathrm{H}_{29}, M_{n}=3.9 \mathrm{kDa}, \bigoplus_{\mathrm{M}}=1.04\right)$ to palm oil BD [107]. In all cases, the lowering of PP was negligible.

In a comparative study of different polymeric CFIs [98], the commercial depressant A-4 (Shanghai Hailian Lubricating Material Technology Co. Ltd., Shanghai, China) was presented as "polymethyl acrylate" without a more detailed description. This polymer did not affect $\mathrm{CP}$ of the waste cooking oil-based methyl esters at concentrations of $0.02-0.08 \mathrm{wt} \%$ but reduced PP by the value of $8{ }^{\circ} \mathrm{C}$. It is noteworthy that the maximum of PP depression was detected for $0.04 \mathrm{wt} \%$ concentration of the additive, and a further increase of the concentration of polyacrylate resulted in an increase of PP. This concentration of the additive was also optimal for CFPP decreased by $6{ }^{\circ} \mathrm{C}$. Polarizing optical microscopy images for neat waste cooking oil BD and BD treated with $0.04 \mathrm{wt} \%$ polymethyl acrylate are presented in Figure 9. In polarizing microscopy analysis, crystals reflect polarized light (white images), amorphous substances absorb light (black images). In neat $\mathrm{BD}$, large crystalline aggregates formed rapidly on cooling from $-10{ }^{\circ} \mathrm{C}$ to $-20^{\circ} \mathrm{C}$ (Figure 9A,B). The presence of polymethyl acrylate revealed the formation of small amounts of crystals at $-10^{\circ} \mathrm{C}$ (Figure $9 \mathrm{C}$ ), and at $-20^{\circ} \mathrm{C}$, some tiny needle-like crystals were formed (Figure 9D). Thus, polymethyl acrylate effectively prevented the aggregation of crystals and transformed the crystal shape. Therefore, lowering PP and CFPP of BD acrylates demonstrated the mechanism of wax crystal modification, similar to the mechanism of the action of EVA copolymers. During the study of the effect of commercial poly(methacrylate) 10-320 (Evonik Oil Additives GmbH, Essen, Germany) on CFI of soybean biodiesel [133], this mechanism was confirmed. 

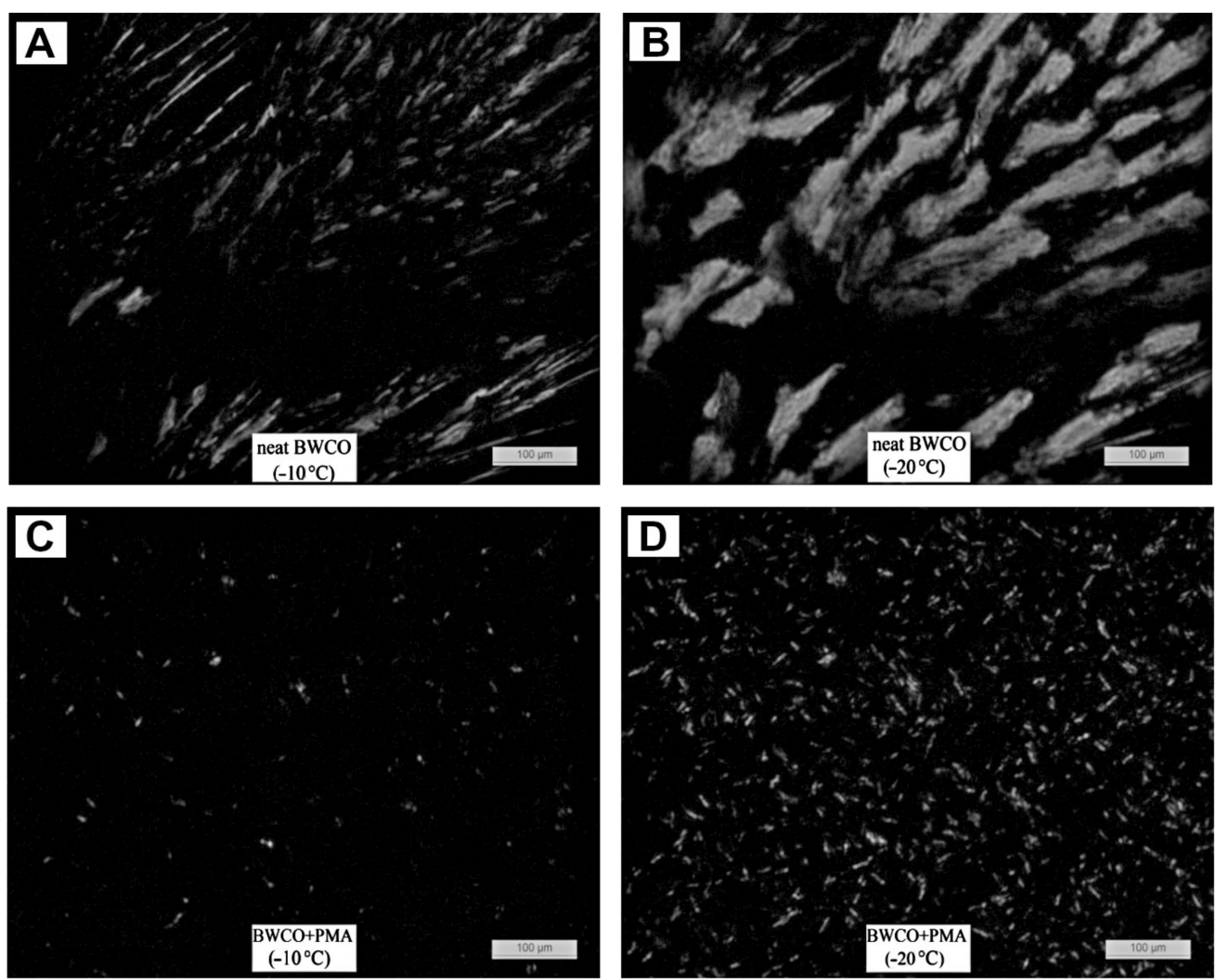

Figure 9. Polarizing optical microscopy images of crystal morphologies of waste cooking oil BD without or with polymethyl acrylate: crystallization of saturated FAMEs without additive at $-10{ }^{\circ} \mathrm{C}(\mathbf{A})$ and $-20{ }^{\circ} \mathrm{C}(\mathbf{B})$, and with additive at $-10{ }^{\circ} \mathrm{C}(\mathbf{C})$ and $-20{ }^{\circ} \mathrm{C}(\mathbf{D})$. Reprinted with permission from [98]. Copyright (2014) Elsevier B.V.

The efficiency of poly(methacrylate) pour point depressant T602 (Tuofu Lubricating Oil Additive Co., Ltd., Hebei, China) was studied by Xue et al. in waste cooking oil BD (32 $\mathrm{wt} \%$ of saturated FAMEs, $\mathrm{CP}=7^{\circ} \mathrm{C}, \mathrm{PP}=5^{\circ} \mathrm{C}$ ) [134]. When $\mathrm{T} 602(0.5 \mathrm{wt} \%)$ was used in combination with Span80 dispersant $(0.25 \mathrm{wt} \%)$, the best synergistic effect on reducing the CFPP by $7{ }^{\circ} \mathrm{C}$ was detected. Commercial pour point depressant Wintron Synergy (Biofuel Systems Group LTD, Ormskirk, UK), which is a combination of polymethacrylate compounds in a solution of mineral oil, demonstrated $\mathrm{CP}$ decrease of canola oil methyl esters by $5{ }^{\circ} \mathrm{C}$ when $2 \mathrm{wt} \%$ of the additive was used [135].

The use of poly(acrylate) CFIs was also presented in the patent literature. $0.5-1 \mathrm{wt} \%$ of poly(alkyl methacrylate)s, prepared from $\mathrm{C}_{12}-\mathrm{C}_{18}$ linear alcohols, demonstrated reduction of PP for soybean oil methyl esters up to $12{ }^{\circ} \mathrm{C}$, and for palm oil methyl esters up to $9^{\circ} \mathrm{C}$ [110]. The effect of the polyacrylates on biodiesel with low content of saturated fatty acids $(\sim 10 \%$, rapeseed oil methyl esters or 1:1 blend of rapeseed and soybean oil methyl esters) was studied by Mähling et al. [126]. For $0.1 \mathrm{wt} \%$ concentration of poly(dodecylpentadecyl methacrylate) $\left(M_{n}=3.74 \mathrm{kDa}, \bigoplus_{\mathrm{M}}=1.54\right)$, the lowering of PP and CFPP was $3^{\circ} \mathrm{C}$. For $0.3 \mathrm{wt} \%$ concentration of the copolymer of stearyl methactylate and lauryl methacrylate $\left(M_{\mathrm{n}}=8.5 \mathrm{kDa}, \bigoplus_{\mathrm{M}}=1.72\right)$, the lowering of PP was $9^{\circ} \mathrm{C}$; the maximum reduction of CFPP $\left(6^{\circ} \mathrm{C}\right)$ was detected when this copolymer was used in $0.5 \mathrm{wt} \%$ concentration [126]. For soybean oil $\mathrm{BD}\left(\mathrm{CP}=-2.5^{\circ} \mathrm{C}, \mathrm{PP}=-5^{\circ} \mathrm{C}\right)$, the addition of $0.1 \mathrm{wt} \%$ of poly(lauryl acrylate)- $b$-poly(lauryl acrylate/stearyl methacrylate) reduced the PP by $5{ }^{\circ} \mathrm{C}$ [136].

The recent work of Muniz et al. [137] deserves special mention. To improve the CFP of soybean oil $\mathrm{BD}\left(\mathrm{CP}=-1{ }^{\circ} \mathrm{C}, \mathrm{PP}=-1{ }^{\circ} \mathrm{C}\right)$, they synthesized a series of polyacrylates that contained oleyl or/and dodecyl fragments; unsaturated copolymers were then functionalized by acid-catalyzed reactions with hydroquinone (Scheme 4). The effect of these additives on the CFP of soybean oil BD is presented in Figure 10. 


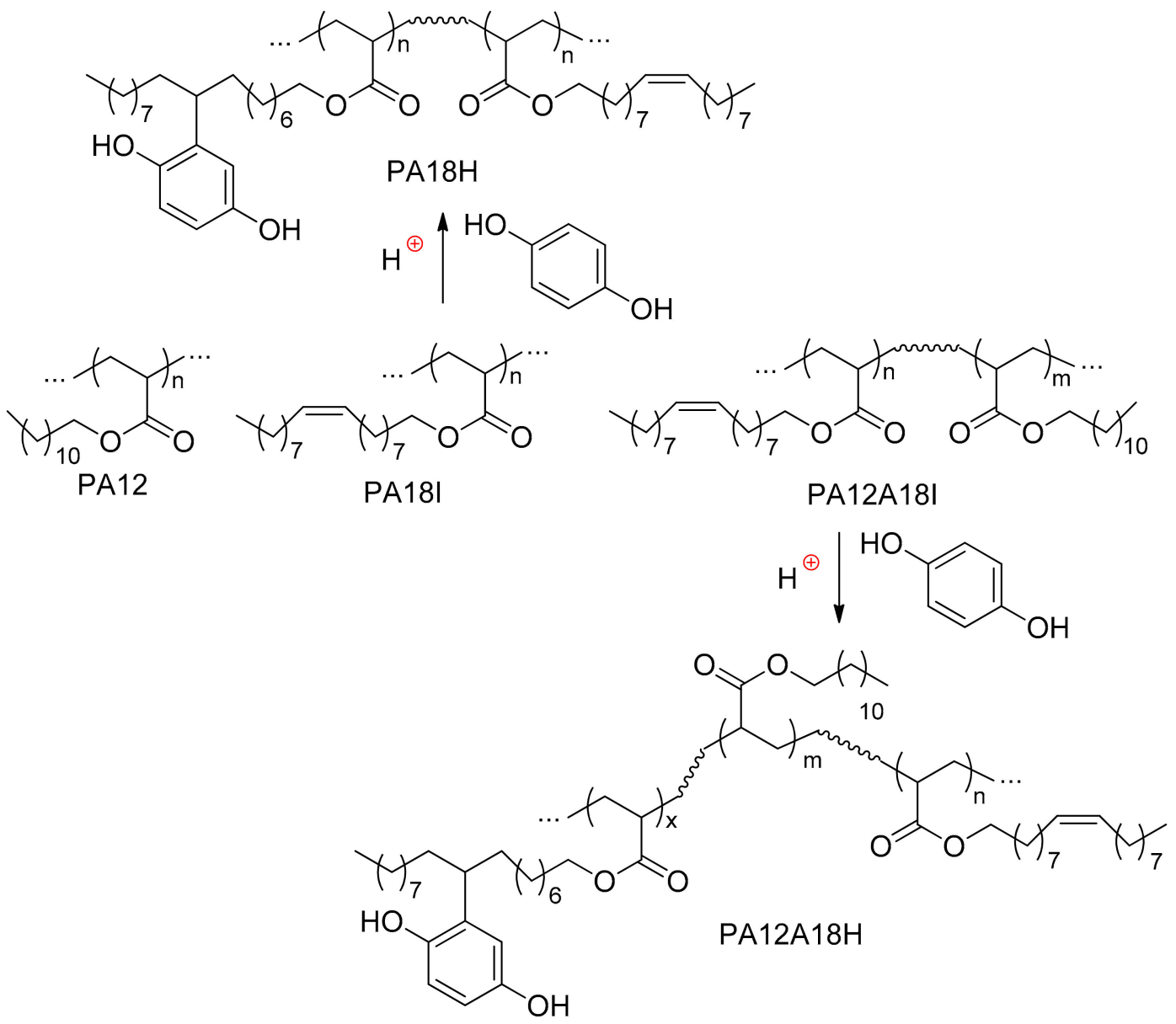

Scheme 4. Structures of poly(acrylates) and the preparation of hydroquinone-functionalized polyacrylates [137].
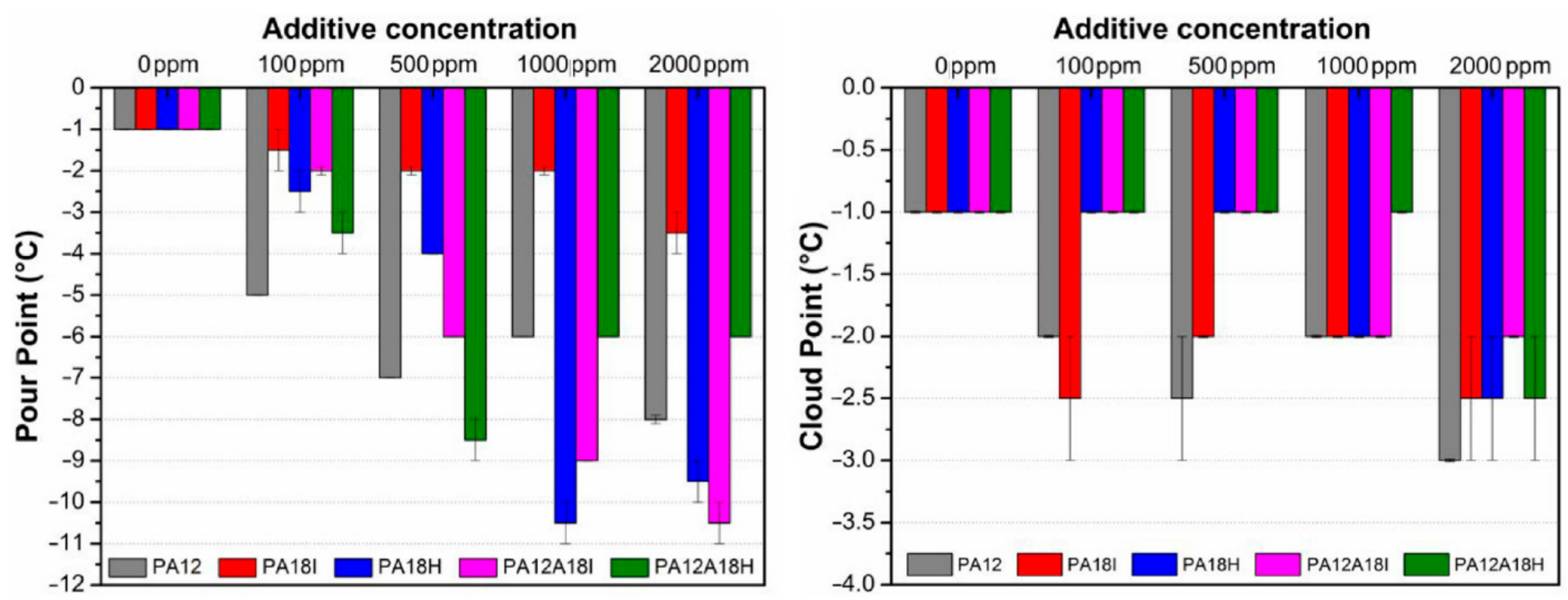

Figure 10. PP (left) and CP (right) of soybean oil BD with and without additives. Reprinted with permission from [137]. Copyright (2020) American Chemical Society.

Mohanan et al. [54] demonstrated a marked synergistic effect of the use of poly(lauryl methacrylate) as PPD in combination with low molecular weight crystallization modifiers, derivatives of vegetable oils. In such mixtures, crystallization modifiers delay the crystallization and form crystals with surface characteristics most favorable for adsorbing the 
PPD. As a result, these complex additives not only affect the nucleation and crystal growth but also provide a barrier to agglomeration, thus preventing the gelling of the biodiesel for an extended temperature range. PP depression for soybean oil methyl esters reached $30{ }^{\circ} \mathrm{C}$ for poly (lauryl methacrylate) loading of $0.5 \mathrm{wt} \%$.

Note that Sern et al. reported no effect of the poly (octadecyl methacrylate) additive for palm oil BD up to $2 \mathrm{wt} \%$ concentrations [105].

\subsection{Maleic Anhydride Copolymers and Their Derivatives}

Copolymers of maleic anhydride (MA) with different vinyl substrates are highly attractive due to the possibility of the further modification of the succinic anhydride fragments formed during polymerization. Usually, such modification is imidization or esterification (Scheme 5).

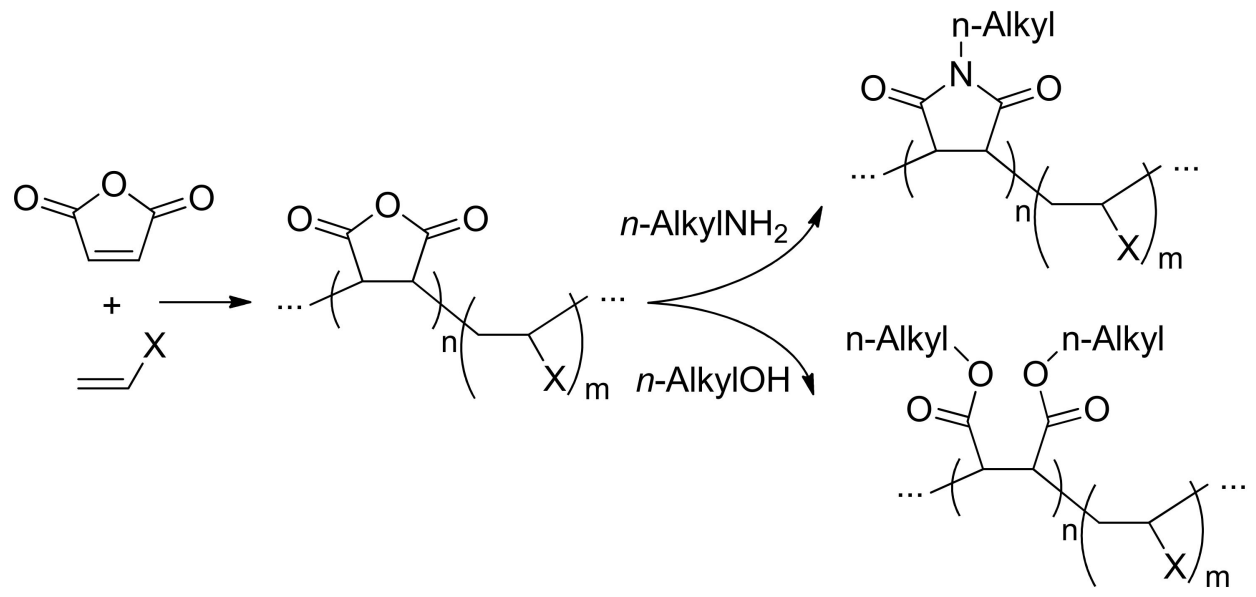

Scheme 5. The synthesis and further modification of maleic anhydride copolymers.

Copolymers of MA with C14, C16 and C18 n-alkyl methacrylates were synthesized and modified by the reaction with tetradecylamine [104]. These copolymers were studied as CFIs for waste oil biodiesel. For $0.05 \mathrm{wt} \%$ concentrations of additives, the lowering of $\mathrm{PP}$ was $13^{\circ} \mathrm{C}, 12^{\circ} \mathrm{C}$ and $10^{\circ} \mathrm{C}$ for imide-functionalized copolymers of MA with C14, C16 and $\mathrm{C} 18$-alkyl methacrylates, respectively.

Copolymers of MA with donor monomers are usually attributed to alternating copolymers [138-144], and the preference of the formation of alternating sequences in free-radical copolymerization of MA with different olefins was confirmed by the density functional theory (DFT) simulations [145]. The wide spectra of the functional derivatives of MA copolymers are considered as highly efficient depressor additives and flow improvers for petroleum fuels [146-148].

Poly(MA-alt-1-octadecene) reduced PP of palm oil BD by $6{ }^{\circ} \mathrm{C}$ being used in $2 \mathrm{wt} \%$ concentration [105]. For tobacco seed oil (12 wt\% of saturated FAMEs), the use of $1 \mathrm{wt} \%$ of poly(MA-alt-1-octadecene) reduced CFPP by the value of $7{ }^{\circ} \mathrm{C}$ [149]. The copolymer of MA with octadecyl vinyl ether $\left(M_{n}=7.0 \times 10^{3} \mathrm{Da}\right)$ in $1 \mathrm{wt} \%$ concentration lowered PP of canola BD by $3^{\circ} \mathrm{C}[100]$.

The products of the reaction of poly(MA-alt- $\left.\mathrm{C}_{18} \mathrm{H}_{36}\right)\left(\mathrm{M}_{\mathrm{n}} 3300 \mathrm{Da}\right)$ with a mixture of tetradecanol, $\mathrm{BnOH}$ and $\mathrm{C}_{12}-\mathrm{C}_{18}$ aliphatic amines [150] in $100 \mathrm{ppm}$ concentration reduced $\mathrm{CP}$ of $\mathrm{BD}$ by $5{ }^{\circ} \mathrm{C}$. Tasić et al. reported that MA-olefin-acrylate copolymers, functionalized by aliphatic amides, demonstrate marked efficiency as CFIs for rapeseed oil BD [151]. However, this work, like many other articles, did not include a detailed description of the copolymer used.

Very recently, we made a comparative study of the effectiveness of a number of conventional CFIs of the EVA copolymer family and octadecanol-functionalized MA copolymers with tetradecene and vinylidene dimers of 1-dodecene and 1-tetradecene (Scheme 6) [152]. 


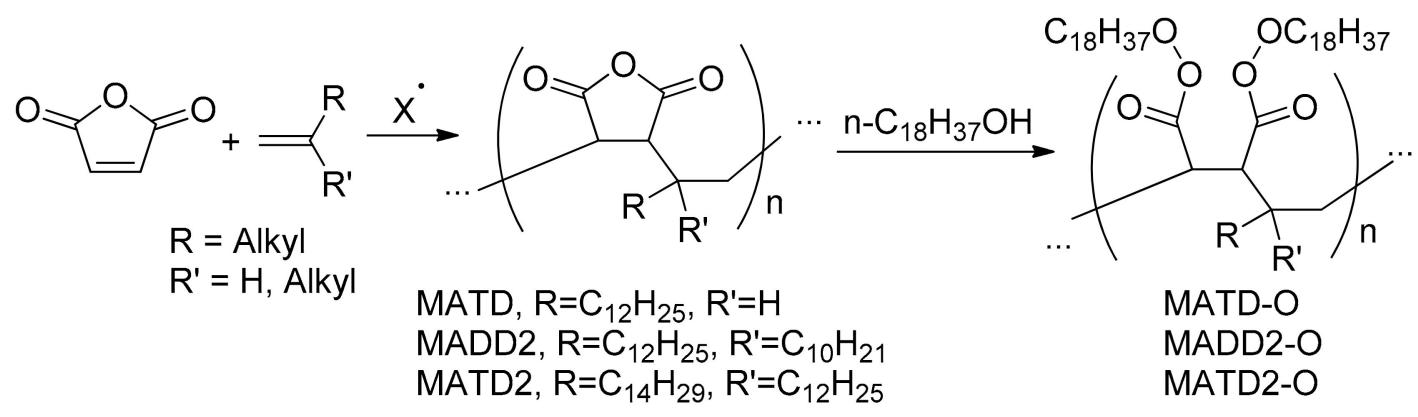

Scheme 6. Copolymerization of maleic anhydride (MA) with olefins and functionalization of poly(MA-alt-olefin)s [152].

Using precision rheometry (Figure 11) and DSC, we demonstrated that functionalized MA copolymer with 1-tetradecene dimer demonstrated promising characteristics as CFIs for corn oil BD ( $23 \%$ of saturated FAMEs). Note that high effectiveness was observed for maleic anhydride copolymer with long-chain branched hydrocarbon, dimer of 1-tetradecene. Additionally, note that the standard methods of determining $\mathrm{CP}$ and PP could not detect subtle differences in biodiesel rheology at subzero temperatures, a proper comparison of the effectiveness of polymer additives requires the use of more knowledge-intensive methods such as precision rheometry and DSC.

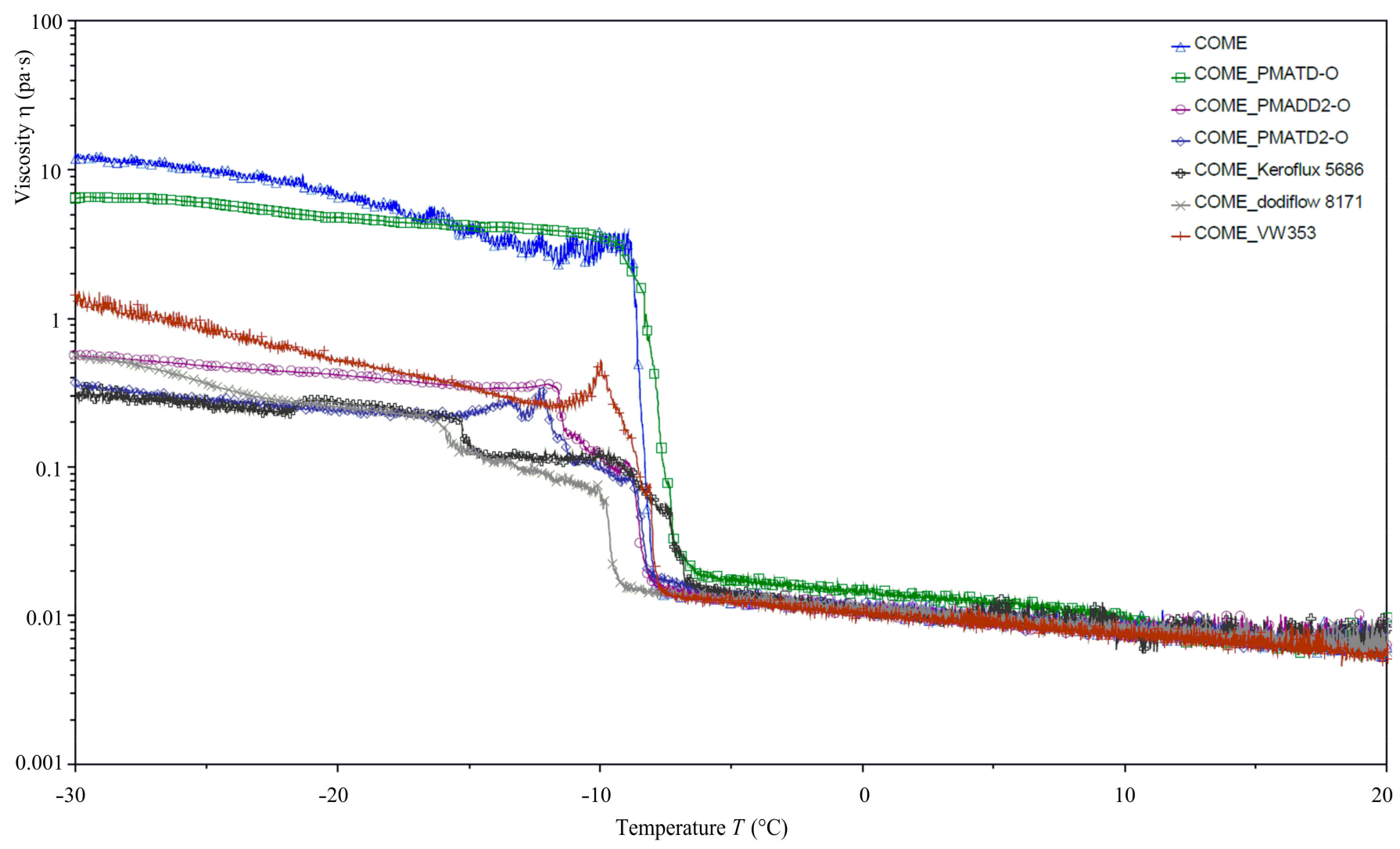

Figure 11. Viscosity vs. temperature curves for corn oil biodiesel (corn oil methyl esters, COME) and COME containing $0.1 \mathrm{wt} \%$ polymer additives. Reprinted with permission from [152]. Copyright (2021) Elsevier B.V.

\subsection{Other Polymeric CFIs}

Promising results were obtained for the mixtures of methacrylate grafted EVAs and poly(methacrylates) [126]. Addition of $0.3 \mathrm{wt} \%$ of $1: 1$ mixture of dodecyl-pentadecyl methacrylate grafted EVA $\left(M_{\mathrm{n}}=51.17 \mathrm{kDa}, \Xi_{\mathrm{M}}=2.14\right)$ with poly(dodecyl-pentadecyl 
methacrylate $)\left(M_{n}=3.74 \mathrm{kDa}, \bigoplus_{M}=1.54\right)$ to $1: 1$ blend of rapeseed and soybean oil methyl esters resulted in reducing of CFPP and PP by the values of $5^{\circ} \mathrm{C}$ and $15^{\circ} \mathrm{C}$, respectively.

A number of terpolymers were synthesized by free-radical copolymerization of alkyl methacrylates, $N$-hexadecylmethacrylamide and vinyl acetate using benzoyl peroxide (BPO) as an initiator [109] (Scheme 7). At a high concentration of the additive (0.5 wt $\%)$, the lowering of PP and CFPP was less than $5{ }^{\circ} \mathrm{C}$.

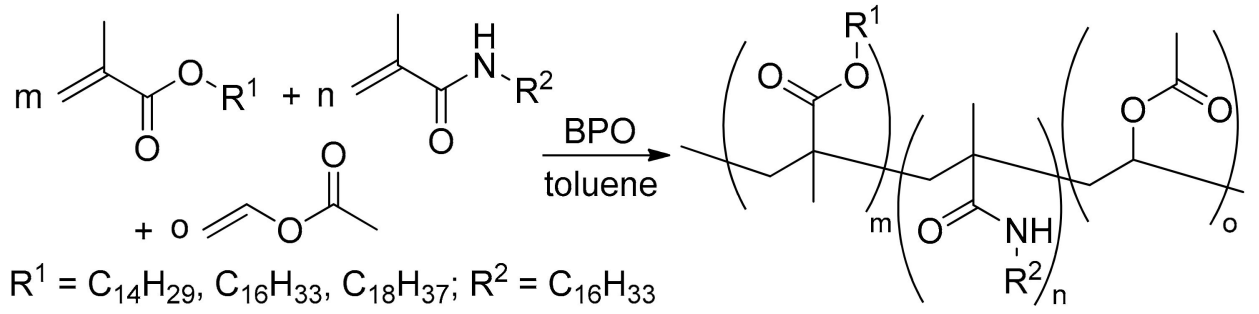

Scheme 7. The synthesis of methacrylate/methacrylamide/VA terpolymers [108].

Tesfaye and Katiyar studied oligomers of L-lactic acid $\left(M_{n} \sim 1 \mathrm{kDa}\right)$ as CFIs for soybean oil $\mathrm{BD}\left(\mathrm{CP}=4{ }^{\circ} \mathrm{C}, \mathrm{PP}=-2{ }^{\circ} \mathrm{C}\right)$ and established only limited effect even at $2 \mathrm{wt} \%$ concentration of the additive [153]. It is significant, however, that low-MW poly(L-lactide) substantially reduced the $\mathrm{CP}$ of the soybean oil $\mathrm{BD}$ (to $0^{\circ} \mathrm{C}$ ) without affecting the PP.

\section{Polymer Additives for BD/Petroleum Diesel Blends}

Obviously, strictly BDs represent fuels with not good cold-flow properties. Separation of the components with high melting points (winterization, $[6,90,154])$ considerably complicates BD production and makes this process more expensive. To date, the blending of BDs with petroleum diesel is the most efficient and commonly used approach to involve BDs in the global fuel industry $[11,17,20,21]$. However, even several per cent of the esters of saturated fatty acids have a negative effect on CFP. The improvement of the CFP $\mathrm{BD} /$ petroleum diesel blends is certainly an actual problem.

The effect of polyolefin PPDs (copolymers of $\mathrm{C}_{9}-\mathrm{C}_{22} \alpha$-olefins) on CFP of waste cooking oil BD blends with petroleum diesel was studied by Xue et al. [102]. They demonstrated that polyolefin additive is effective cold-flow improver for the mixture of BD $(25 \%$ of saturated FAMEs, $\left.\mathrm{CP}=7^{\circ} \mathrm{C}, \mathrm{PP}=5^{\circ} \mathrm{C}\right)$ with petroleum diesel $\left(\mathrm{CP}=-1^{\circ} \mathrm{C}, \mathrm{PP}=-10^{\circ} \mathrm{C}\right)$, containing $20 \mathrm{vol} \%$ of BD. For optimal concentration $(0.04 \mathrm{wt} \%)$, the lowering of $\mathrm{CP}$ and PP were $8{ }^{\circ} \mathrm{C}$ and $7{ }^{\circ} \mathrm{C}$, respectively. In addition, the presence of polyolefin additives substantially reduced the low-temperature viscosity of $\mathrm{BD} /$ petroleum diesel blends.

The results of the first comparative study of the effect of different additives on CFP of soybean BD/petroleum diesel blends were reported by Chui et al. [97]. The optimum concentrations of the additives were found to be $0.2-0.5 \mathrm{wt} \%$. Unfortunately, this work does not contain any data concerning the composition of the additives used; it is only noted that all additives contain EVA copolymers. The influence of EVA copolymer on CFP of the blends of waste cooking oil BD $\left(\sim 42 \%\right.$ of saturated methyl esters, $\mathrm{CP}=5{ }^{\circ} \mathrm{C}$, $\left.\mathrm{PP}=2{ }^{\circ} \mathrm{C}\right)$ with petroleum diesel $\left(\mathrm{CP}=-4{ }^{\circ} \mathrm{C}, \mathrm{PP}=-8{ }^{\circ} \mathrm{C}\right)$ was studied by Cat et al. [103]. They found that EVA copolymer, which is effective PPD for petroleum diesel (reducing of $\mathrm{CP}, \mathrm{CFPP}$ and $\mathrm{PP}$ by 8,11 and $10{ }^{\circ} \mathrm{C}$, respectively, when $0.08 \mathrm{wt} \%$ of the additive was used), maintains its efficiency for $\mathrm{BD} /$ petroleum diesel blends that contain $40 \mathrm{vol} \%$ of $\mathrm{BD}$ and less. For B20 blend (20 vol\% BD) and $0.08 \mathrm{wt} \%$ concentration of the EVA copolymer, the lowering of CP, CFPP and PP was the same 8, 11 and $10^{\circ} \mathrm{C}$; for $\mathrm{B} 40$ blend, the effect was significantly weaker $\left(6,6\right.$ and $5^{\circ} \mathrm{C}$, respectively).

Note that the impact of the EVA copolymers on CFP of the blends of rapeseed oil methyl esters $\left(\mathrm{CP}=-4{ }^{\circ} \mathrm{C}, \mathrm{CFPP}=-11^{\circ} \mathrm{C}\right)$ with petroleum diesel $\left(\mathrm{CP}=-3{ }^{\circ} \mathrm{C}\right.$, $\mathrm{CFPP}=-5^{\circ} \mathrm{C}$ ) was demonstrated by Davies et al. back in 1998 [155]. For pure rapeseed oil BD, the lowering of CFPP was only $2{ }^{\circ} \mathrm{C}(320 \mathrm{ppm}$ loading of the EVA copolymer, 
$36 \mathrm{wt} \%$ vinyl acetate, $M_{\mathrm{n}}=2.4 \mathrm{kDa}$ ), while for B50 blend, CFPP was reduced from $-10{ }^{\circ} \mathrm{C}$ to $-27^{\circ} \mathrm{C}$.

The addition of $0.03 \mathrm{wt} \%$ poly(methyl acrylate) reduced the PP, CP, and CFPP of coconut $\mathrm{BD}(90.2 \%$ saturated, $7.7 \%$ monounsaturated and $2.1 \%$ polyunsaturated FAMEs) blend with petroleum diesel ( $20 \mathrm{vol} \%$ of $\mathrm{BD}$ ) by $9{ }^{\circ} \mathrm{C}, 3^{\circ} \mathrm{C}$ and $8{ }^{\circ} \mathrm{C}$, respectively [156]. Very close results were reported for the same blend in [157].

Cold flow properties of BD blends with petroleum diesel in the presence of poly(methyl acrylate) additive were studied by Islam et al. [158]. Cocos nucifera (coconut) BD (89.2 wt $\%$ of saturated FAMEs, $\left.\mathrm{CP}=14{ }^{\circ} \mathrm{C}, \mathrm{PP}=13^{\circ} \mathrm{C}\right)$ and Calophyllum inophyllum $\mathrm{BD}(32.9 \%$ of saturated FAMEs, $\left.\mathrm{CP}=1{ }^{\circ} \mathrm{C}, \mathrm{PP}=-3^{\circ} \mathrm{C}\right)$ were mixed with petroleum diesel $\left(\mathrm{CP}=-5^{\circ} \mathrm{C}\right.$, $\mathrm{PP}=-5^{\circ} \mathrm{C}$ ), the maximum effect of the additive in B10-B30 blends was detected for $\sim 0.03 \mathrm{wt} \%$ concentrations. The best results were obtained for B20 blends; the CP, PP and CFPP were reduced by $6{ }^{\circ} \mathrm{C}, 9^{\circ} \mathrm{C}$ and $12{ }^{\circ} \mathrm{C}$, respectively, for coconut $\mathrm{BD}$ blend and by $5{ }^{\circ} \mathrm{C}, 6^{\circ} \mathrm{C}$ and $6{ }^{\circ} \mathrm{C}$, respectively, for Calophyllum inophyllum $\mathrm{BD}$ blend.

Palm oil BD blends with petroleum diesel in the presence of a series of low-MW poly(alkyl acrylates) and poly(alkyl methacrylates) demonstrated a significant reduction in PP. The best results were obtained for the copolymer of poly(acrylic acid) and poly(tetradecyl methacrylate) used in $0.1 \mathrm{wt} \%$ concentration: for the $\mathrm{B} 5 \mathrm{blend}$, the reduction was $26{ }^{\circ} \mathrm{C}$, for the B20 blend, it was $7{ }^{\circ} \mathrm{C}$ [107]. Terpolymers of C12-C15 alkyl methacrylates, $\mathrm{C} 18-\mathrm{C} 18$ alkyl methacrylates and methyl methacrylate (75:15:10 by weight, $M_{\mathrm{n}}=56 \mathrm{kDa}, \bigoplus_{\mathrm{M}}=2.3$ ) reduced PP of palm oil-based B20 blend by $3{ }^{\circ} \mathrm{C}$ [159].

Lin et al. recently reported the synthesis of the terpolymers of C14 or C16n-alkyl methacrylate, benzyl methacrylate (BM) and N-vinylpyrrolidone (NVP) [160] by freeradical copolymerization on the basis of 1-20:1:1 comonomer ratios (Scheme 8). Similar copolymers, based on C12, C14, C16 and C18 alkyl methacrylates, were studied by $\mathrm{Su}$ et al. as PPDs for the blends of the waste cooking oil BD (38.4 $\mathrm{wt} \%$ of saturated FAMEs, $\left.\mathrm{CP}=7{ }^{\circ} \mathrm{C}, \mathrm{PP}=5^{\circ} \mathrm{C}\right)$ with petroleum diesel $\left(\mathrm{CP}=-1{ }^{\circ} \mathrm{C}, \mathrm{PP}=-12{ }^{\circ} \mathrm{C}\right)[161]$.

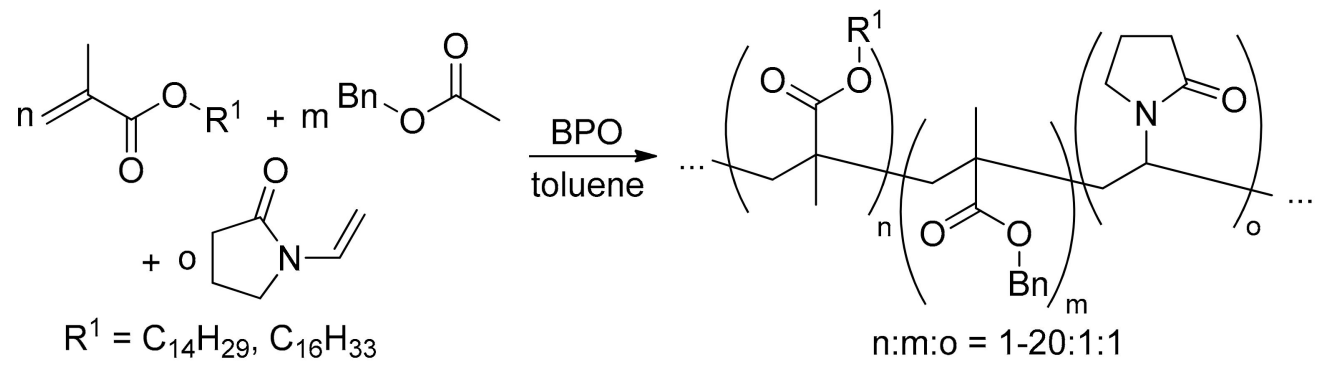

Scheme 8. The synthesis of methacrylate/ $N$-vinylpyrrolidone terpolymers [160].

The results of this study for B20 blends are presented in Figure 12. When the terpolymers have different monomer proportions, with decreasing ratio of the NVP comonomer, the depressing effect initially increased and then decreased. When the $n$-alkyl methacrylate/BM/NVP molar ratio of the terpolymer was 5:1:1, $\triangle$ CFPP had the best reducing effect. The best results were achieved when C16MA-BM-NVP copolymers were used at the dosage of $2000 \mathrm{ppm}(0.2 \mathrm{wt} \%)$. This result was attributed by the authors to the principle of carbon chain matching: the long carbon chain of C16MC-MB-NVP co-crystallizes with high melting point methyl palmitate, and the polar group of the PPD increases the dispersion of wax crystals. The further improvement of the CFP of B20 blends was achieved through the use of dispersants such as fatty alcohol polyoxyethylene ethers. 


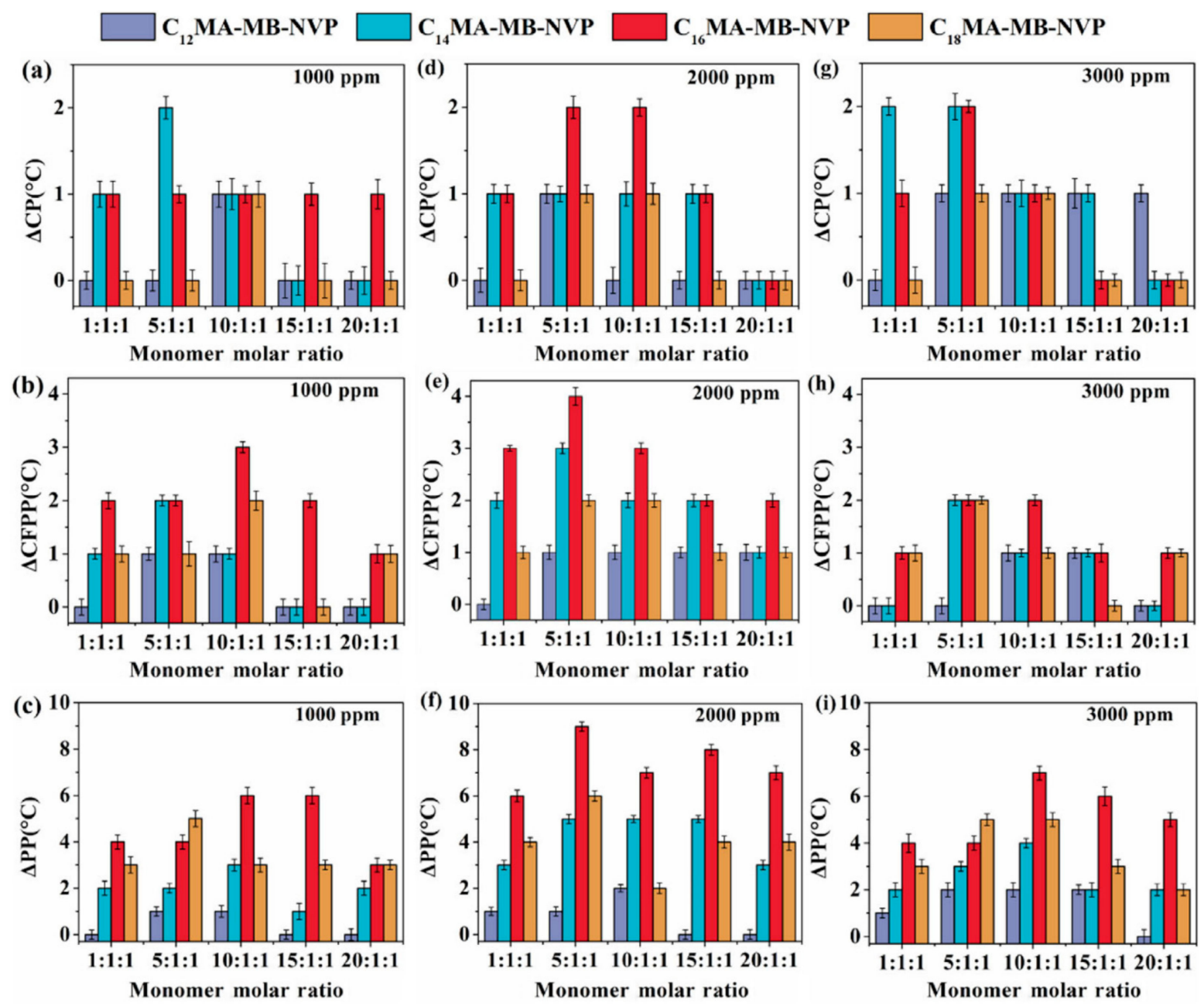

Figure 12. Effects of 1000 ppm (a-c), 2000 ppm (d-f), and 3000 ppm (g-i) RMC-BM-NVP terpolymers on $\triangle \mathrm{CP}, \triangle \mathrm{CFPP}$, and $\triangle$ PP of B20 (RMCMB-NVP = methacrylate-benzyl methacrylate- $N$-vinyl-2-pyrrolidone terpolymers, $\mathrm{R}=\mathrm{C} 12, \mathrm{C} 14, \mathrm{C} 16$, C18). Reprinted with permission from [161]. Copyright (2020) Wiley-VCH Verlag GmbH \& Co.

\section{Conclusions and Perspectives}

The cold-flow properties of biodiesel have an important role in determining its suitability as alternative fuel or fuel component in moderate temperature climates. The use of polymer additives, pour point depressants and dispersants can often provide a substantial improvement of the CFP of $\mathrm{BD}$. It is possible that polymeric cold-flow improvers can enhance the other characteristics of $\mathrm{BD}$ and $\mathrm{BD} /$ petroleum diesel blends; for example, the combined effect of hydroquinone-functionalized poly(acrylate)s as CFIs and antioxidants were demonstrated very recently [137].

When one compares the performance of polymer CFIs in BD and in petroleum diesel, the fact is many types of additives are highly effective in petroleum diesel and demonstrate little impact on the CFP of BD. However, these additives are fully effective if used in $\mathrm{BD} /$ petroleum diesel blends containing no more than $20 \mathrm{vol} \%$ of BD. Perhaps, it is exactly blending with petroleum diesel in combination with the use of polymer CFIs that would increase the global use of BD [30].

We also note that the experimental data, presented in several articles, devoted to the application of the polymer additives for the improvement of the CFP of BD [32,97-99,102,108,134,151,156,158,162-164], are scientifically irrelevant in the context of our review due to lack of the objective characteristics of the polymers under study: the references on the trade names of the commercial additives are clearly insufficient, given in mind that the recipes of such additives are commercial secrets. Undoubtedly, the high 
relevance of the biodiesel thematics (Figure 3) attracts the researchers by the possibility of the publication of raw and incomplete results as fully fledged research papers, and in some cases, the patent literature contained more comprehensive data (Table 3). It was to be hoped that further contributions in the field of the improvement of BD characteristics would be made at a more senior level that had long been accepted in top-rated studies of petrochemical products.

Table 3. The summary of the data on polymer CFIs for biodiesel.

\begin{tabular}{|c|c|c|c|c|c|c|c|c|c|}
\hline \multicolumn{2}{|c|}{ Biodiesel } & \multicolumn{3}{|c|}{ Polymer CFIs Added } & \multirow{2}{*}{$\begin{array}{c}\Delta \mathrm{CP}, \\
{ }^{\circ} \mathrm{C}\end{array}$} & \multirow{2}{*}{$\begin{array}{l}\Delta \mathrm{PP}, \\
{ }^{\circ} \mathrm{C}\end{array}$} & \multirow{2}{*}{$\begin{array}{c}\Delta \mathrm{CFPP}, \\
{ }^{\circ} \mathrm{C}\end{array}$} & \multicolumn{2}{|c|}{ Reference } \\
\hline Name & $\begin{array}{c}\text { Saturated } \\
\text { FAMEs wt } \%\end{array}$ & Type & $\begin{array}{c}\text { Composition/ } \\
\mathrm{MW} / \oplus_{\mathrm{M}}\end{array}$ & $\begin{array}{c}\text { Concentration, } \\
\text { wt } \%\end{array}$ & & & & No. & Rating ${ }^{1}$ \\
\hline Canola & 6.2 & EVA & $--^{2} /-/-$ & 1 & 0 & 11 & - & 100 & Q1 \\
\hline Canola & 6.2 & poly(acrylate) & $+/+/+$ & $0.5-1$ & - & 30 & - & 100 & Q1 \\
\hline Canola & - & poly(acrylate) & $-1-1-$ & 2 & 5 & - & - & 135 & Q1 \\
\hline Canola & - & $\mathrm{MA} / \mathrm{C}_{18} \mathrm{OCH}=\mathrm{CH}_{2}$ & $+/+1-$ & 1 & - & 3 & - & 100 & Q1 \\
\hline Rapeseed & - & MA/olefin/acrylate & $-/-/-$ & 0.5 & - & 2 & 4 & 151 & Q3 \\
\hline Rapeseed & $\sim 10$ & poly(acrylate) & $+/+/+$ & $0.3-0.5$ & - & 9 & 6 & 126 & $\widehat{P}$ \\
\hline Rapeseed/soybean & 10.0 & EVA-g-acrylate & $+/+/+$ & 0.5 & - & 15 & 5 & 126 & $\mathrm{P}$ \\
\hline Rapeseed/soybean & 10.0 & EVA-acrylate & $+/+/+$ & 0.3 & 2 & - & 9 & 126 & $\mathrm{P}$ \\
\hline Soybean & 14.3 & EVA & $-1-1-$ & 0.01 & - & 2 & 1 & 106 & Q1 \\
\hline Soybean & 17.4 & poly(acrylate) & $-1-1-$ & $0-1$ & - & - & 0 & 133 & $\widehat{\mathrm{Q}} 1$ \\
\hline Soybean & - & poly(acrylate) & $-1-1-$ & $0.5-1$ & - & 12 & - & 110 & $\mathrm{P}$ \\
\hline Soybean & - & poly(acrylate) & $+/+/+$ & 0.1 & - & 5 & - & 136 & $\mathrm{P}$ \\
\hline Soybean & - & poly(acrylate) & $+/+/+$ & 0.2 & 3 & 9 & - & 137 & Q1 \\
\hline Soybean & 14.5 & poly(acrylate) & $-1-1-$ & 0.5 & - & 30 & - & 24 & Q1 \\
\hline Palm & 43.6 & polyolefin & 1-decene/-/- & $0-2$ & 0 & 0 & 0 & 105 & Q1 \\
\hline Palm & 46 & EVA & $-/-/-$ & 1 & - & & 6 & 127 & Q1 \\
\hline Palm & - & poly(acrylate) & $+/+/+$ & $0.01-0.1$ & - & 0 & - & 107 & $\hat{\mathrm{Q} 3}$ \\
\hline Palm & - & poly(acrylate) & $-1-1-$ & $0.5-1$ & - & 9 & - & 110 & $\mathrm{P}$ \\
\hline Palm & 36.9 & poly(acrylate) & $+1-1-$ & $0-2$ & 0 & 0 & 0 & 105 & Q1 \\
\hline Palm & 36.9 & $\mathrm{MA} / \mathrm{C}_{18}$ & $+1-1-$ & 2 & - & 6 & - & 105 & Q1 \\
\hline Tobacco seed & 12 & $\mathrm{MA} / \mathrm{C}_{18}$ & $+1-1-$ & 1 & - & - & 7 & 149 & $\hat{\mathrm{Q}} 1$ \\
\hline Waste cooking & - & polyolefin & $-1-1-$ & 0.1 & - & $2-3$ & $2-3$ & 108 & $\hat{\mathrm{Q} 2}$ \\
\hline Waste cooking & - & polyolefin & $-1-1-$ & $0.02-0.08$ & 1 & 1 & 3 & 98 & Q1 \\
\hline Waste cooking & - & EVA & $-1-1-$ & $0.02-0.08$ & 2 & 6 & 2 & 98 & Q1 \\
\hline Waste cooking & 43.5 & EVA & $-1-1-$ & $0.02-0.08$ & 0 & 3 & 1 & 103 & Q1 \\
\hline Waste cooking & - & poly(acrylate) & $-1-1-$ & $0.02-0.08$ & 0 & 8 & 6 & 98 & Q1 \\
\hline Waste cooking & 32 & poly(acrylate) & $-/-/-$ & 0.5 & - & - & 7 & 134 & Q3 \\
\hline Waste cooking & - & $\mathrm{MA} /$ acrylate $/ \mathrm{C}_{14} \mathrm{~N}$ & $+1-1-$ & 0.05 & - & 13 & - & 104 & Q3 \\
\hline- & - & $\mathrm{MA} / \mathrm{C}_{18} / \mathrm{ON}^{3}$ & $+/+/+$ & 0.01 & 5 & - & - & 150 & $\mathrm{P}$ \\
\hline- & - & acrylate/acrylamide & $-1-/-$ & 0.5 & - & $<5$ & $<5$ & 109 & $\mathrm{P}$ \\
\hline
\end{tabular}

${ }^{1}$ Q1-Q4-SJR rating, https:/ / www.scimagojr.com/journalrank.php, accessed on 1 April 2021. P—patent or patent application. ${ }^{2}$ No data presented. ${ }^{3}$ Modified by aliphatic alcohols and amines.

We are assuming that the further development of the polymer cold-flow improvers for biodiesel and biodiesel blends should include a more detailed and precise analysis and discussion of the nature of additive, combined with modern research methods (precision rheometry, DSC, SFC NMR, etc.). The global objective is to create the library of polymer cold-flow improvers for petroleum diesel, biodiesel and petroleum diesel /biodiesel blends, which would ensure economically viable and technically competent employment of biodiesel in the global fuel industry.

Author Contributions: Conceptualization, I.N. and P.I.; methodology, I.N.; software, P.I.; writing-original draft preparation, P.I.; writing-review and editing, I.N.; visualization, P.I.; supervision, I.N.; project administration, I.N.; funding acquisition, I.N. All authors have read and agreed to the published version of the manuscript.

Funding: This research was funded by Russian Science Foundation, grant number 21-73-30010.

Conflicts of Interest: The authors declare no conflict of interest. 


\section{References}

1. Huber, G.W.; Iborra, S.; Corma, A. Synthesis of transportation fuels from biomass: Chemistry, catalysts, and engineering. Chem. Rev. 2006, 106, 4044-4098. [CrossRef] [PubMed]

2. Shylesh, S.; Gokhale, A.A.; Ho, C.R.; Bell, A.T. Novel strategies for the production of fuels, lubricants, and chemicals from biomass. Acc. Chem. Res. 2017, 50, 2589-2597. [CrossRef]

3. Biofuels Dashboard 2020. Available online: https://www.ifpenergiesnouvelles.com/article/biofuels-dashboard-2020 (accessed on 15 April 2021).

4. ExxonMobil. The Outlook for Energy: A View to 2040. Available online: https://corporate.exxonmobil.com/Energy-andinnovation/outlook-for-energy (accessed on 15 April 2021).

5. Higher Blending Mandates in Key Markets Support Global Biodiesel and HVO Output in 2020. Available online: https: //www.iea.org/reports/renewables-2020/transport-biofuels (accessed on 15 April 2021).

6. Dwivedi, G.; Sharma, M.P. Impact of cold flow properties of biodiesel on engine performance. Renew. Sustain. Energy Rev. 2014, 31, 650-656. [CrossRef]

7. Dwivedi, G.; Sharma, M.P. Cold flow behavior of biodiesel-A review. Int. J. Renew. Energy Resour. 2013, 3, 827-836.

8. Demirbas, A. Biodiesel fuels from vegetable oils via catalytic and non-catalytic supercritical alcohol transesterifications and other methods: A survey. Energy Convers. Manag. 2003, 44, 2093-2109. [CrossRef]

9. Gebremariam, S.N.; Marchetti, J.M. Economics of biodiesel production: Review. Energy Convers. Manag. 2018, 168, 74-84. [CrossRef]

10. Basha, S.A.; Gopal, K.R. A review of the effects of catalyst and additive on biodiesel production, performance, combustion and emission characteristics. Renew. Sustain. Energy Rev. 2012, 16, 711-717. [CrossRef]

11. Kannan, G.R.; Anand, R. Biodiesel as an alternative fuel for direct injection diesel engines: A review. J. Renew. Sustain. Energy 2012, 4, 012703. [CrossRef]

12. Bateni, H.; Saraeian, A.; Able, C. A comprehensive review on biodiesel purification and upgrading. Biofuel Res. J. 2017, 4, 668-690. [CrossRef]

13. Kumar, M.; Sharma, M.P. Selection of potential oils for biodiesel production. Renew. Sustain. Chem. Rev. 2016, 56, 1129-1138. [CrossRef]

14. Hoekman, S.K.; Broch, A.; Robbins, C.; Ceniceros, E.; Natarajan, M. Review of biodiesel composition, properties, and specifications. Renew. Sustain. Energy Rev. 2012, 16, 143-169. [CrossRef]

15. Knothe, G.; Razon, L.F. Biodiesel fuels. Progr. Energy Combust. Sci. 2017, 58, 36-59. [CrossRef]

16. Lanjekar, R.D.; Deshmukh, D. A review of the effect of the composition of biodiesel on $\mathrm{NO}_{\mathrm{x}}$ emission, oxidative stability and cold flow properties. Renew. Sustain. Energy Rev. 2016, 54, 1401-1411. [CrossRef]

17. Joshi, G.; Pandey, J.K.; Rana, S.; Rawat, D.S. Challenges and opportunities for the application of biofuel. Renew. Sustain. Energy Rev. 2017, 79, 850-866. [CrossRef]

18. Rodionova, M.V.; Poudyal, R.S.; Tiwari, I.; Voloshin, R.A.; Zharmukhamedov, S.K.; Nam, H.G.; Zayadan, B.K.; Bruce, B.D.; Hou, H.J.M.; Allakhverdiev, S.I. Biofuel production: Challenges and opportunities. Int. J. Hydrog. Energy 2017, 42, 8450-8461. [CrossRef]

19. Azadi, P.; Malina, R.; Barrett, S.R.H.; Kraft, M. The evolution of the biofuel science. Renew. Sustain. Energy Rev. 2017, 76, 1479-1484. [CrossRef]

20. Gaurav, N.; Sivasankari, S.; Kiran, G.S.; Ninawe, A.; Selvin, J. Utilization of bioresources for sustainable biofuels: A Review. Renew. Sustain. Energy Rev. 2017, 73, 205-214. [CrossRef]

21. Acheampong, M.; Ertem, F.C.; Kappler, B.; Neubauer, P. In pursuit of Sustainable Development Goal (SDG) number 7: Will biofuels be reliable? Renew. Sustain. Energy Rev. 2017, 75, 927-937. [CrossRef]

22. Mahmudul, H.M.; Hagos, F.Y.; Mamat, R.; Adam, A.A.; Ishak, W.F.W.; Alenezi, R. Production, characterization and performance of biodiesel as an alternative fuel in diesel engines-A review. Renew. Sustain. Energy Rev. 2017, 72, 497-509. [CrossRef]

23. Hajjari, M.; Tabatabaei, M.; Aghbashlo, M.; Ghanavati, H. A review on the prospects of sustainable biodiesel production: A global scenario with an emphasis on waste-oil biodiesel utilization. Renew. Sustain. Energy Rev. 2017, 72, 445-464. [CrossRef]

24. Mardhiah, H.H.; Ong, H.C.; Masjuki, H.H.; Lim, S.; Lee, H.V. A review on latest developments and future prospects of heterogeneous catalyst in biodiesel production from non-edible oils. Renew. Sustain. Energy Rev. 2017, 67, 1225-1236. [CrossRef]

25. Gopinath, A.; Sairam, K.; Velraj, R.; Kumaresan, G. Effects of the properties and the structural configurations of fatty acid methyl esters on the properties of biodiesel fuel: A review. Proc. Inst. Mech. Eng. Part D J. Automob. Eng. 2014, 229, 357-390. [CrossRef]

26. Kumar, M.; Sharma, M.P. Assessment of potential of oils for biodiesel production. Renew. Sustain. Energy Rev. 2015, 44, 814-823. [CrossRef]

27. Sorate, K.A.; Bhale, P.V. Biodiesel properties and automotive system compatibility issues. Renew. Sustain. Energy Rev. 2015, 41, 777-798. [CrossRef]

28. Sakthivel, R.; Ramesh, K.; Purnachandran, R.; Shameer, P.M. A review on the properties, performance and emission aspects of the third generation biodiesels. Renew. Sustain. Energy Rev. 2018, 82, 2970-2992. [CrossRef]

29. Singh, D.; Sharma, D.; Soni, S.L.; Sharma, S.; Kumari, D. Chemical compositions, properties, and standards for different generation biodiesels: A review. Fuel 2019, 253, 60-71. [CrossRef] 
30. Wu, G.; Ge, J.C.; Choi, N.J. A comprehensive review of the application characteristics of biodiesel blends in diesel engines. Appl. Sci. 2020, 10, 8015. [CrossRef]

31. Ge, J.C.; Yoon, S.K.; Choi, N.J. Using canola oil biodiesel as an alternative fuel in diesel engines: A review. Appl. Sci. 2017, 7, 881. [CrossRef]

32. Dunn, R.O.; Shockley, M.W.; Bagby, M.O. Improving the low-temperature properties of alternative diesel fuels: Vegetable oil-derived methyl esters. J. Am. Oil Chem. Soc. 1996, 73, 1719-1728. [CrossRef]

33. Smith, P.C.; Ngothai, Y.; Nguyen, Q.D.; O'Neill, B.K. Improving the low-temperature properties of biodiesel: Methods and consequences. Renew. Energy 2010, 35, 1145-1151. [CrossRef]

34. Dunn, R.O. Effects of minor constituents on cold flow properties and performance of biodiesel. Progr. Energy Combust. Sci. 2009, 35, 481-489. [CrossRef]

35. Misra, R.D.; Murthy, M.S. Blending of additives with biodiesels to improve the cold flow properties, combustion and emission performance in a compression ignition engine-A review. Renew. Sustain. Energy Rev. 2011, 15, 2413-2422. [CrossRef]

36. Ali, O.M.; Mamat, R.; Faizal, C.K.M. Review of the effects of additives on biodiesel properties, performance, and emission features. J. Renew. Sustain. Energy 2013, 5, 012701. [CrossRef]

37. Monirul, I.M.; Masjuki, H.H.; Kalam, M.A.; Zulkifli, N.W.M.; Rashedul, H.K.; Rashed, M.M.; Imdadula, H.K.; Mosarof, M.H. A comprehensive review on biodiesel cold flow properties and oxidation stability along with their improvement processes. RSC Adv. 2015, 5, 86631-86655. [CrossRef]

38. Liu, G. Development of low-temperature properties on biodiesel fuel: A review. Int. J. Energy Res. 2015, 39, 1295-1310. [CrossRef]

39. Sierra-Cantora, J.F.; Guerrero-Fajardo, C.A. Methods for improving the cold flow properties of biodiesel with high saturated fatty acids content: A review. Renew. Sustain. Energy Rev. 2017, 72, 774-790. [CrossRef]

40. Jing, G.; Yu, H.; Sun, Z.; Zhen, Z. Research progress on biodiesel pour point depressant: A mini-review. Pet. Chem. 2019, 59, 1023-1027. [CrossRef]

41. Leng, L.; Li, W.; Li, H.; Jiang, S.; Zhou, W. Cold flow properties of biodiesel and the improvement methods: A review. Energy Fuels 2020, 34, 10364-10383. [CrossRef]

42. Hazrat, M.A.; Rasul, M.G.; Mofijur, M.; Khan, M.M.K.; Djavanroodi, F.; Azad, A.K.; Bhuiya, M.M.K.; Silitonga, A.S. A mini review on the cold flow properties of biodiesel and its blends. Front. Energy Res. 2020, 8, 598651. [CrossRef]

43. Sia, C.B.; Kansedo, J.; Tan, Y.H.; Lee, K.T. Evaluation on biodiesel cold flow properties, oxidative stability and enhancement strategies: A review. Biocatal. Agric. Biotechnol. 2020, 24, 101514. [CrossRef]

44. Verma, P.; Sharma, M.P.; Dwivedi, G. Evaluation and enhancement of cold flow properties of palm oil and its biodiesel. Energy Rep. 2016, 2, 8-13. [CrossRef]

45. Giraldo, S.Y.; Rios, L.A.; Suárez, N. Comparison of glycerol ketals, glycerol acetates and branched alcohol-derived fatty esters as cold-flow improvers for palm biodiesel. Fuel 2013, 108, 709-714. [CrossRef]

46. Soriano, N.U., Jr.; Migo, V.P.; Matsumura, M. Ozonized vegetable oil as pour point depressant for neat biodiesel. Fuel 2006, 85, 25-31. [CrossRef]

47. Elias, R.C.; Senra, M.; Soh, L. Cold flow properties of fatty acid methyl ester blends with and without triacetin. Energy Fuels 2016, 30, 7400-7409. [CrossRef]

48. Leggieri, P.A.; Senra, M.; Soh, L. Cloud point and crystallization in fatty acid ethyl ester biodiesel mixtures with and without additives. Fuel 2018, 222, 243-249. [CrossRef]

49. De Torres, M.; Jiménez-Osés, G.; Mayoral, J.A.; Pires, E. Fatty acid derivatives and their use as CFPP additives in biodiesel. Bioresour. Technol. 2011, 102, 2590-2594. [CrossRef]

50. Dunn, R.O.; Wyatt, V.T.; Wagner, K.; Ngo, H.; Hums, M.E. The effect of branched-chain fatty acid alkyl esters on the cold-flow properties of biodiesel. J. Am. Oil Chem. Soc. 2019, 96, 805-823. [CrossRef]

51. Sugami, Y.; Yoshidomi, S.; Minami, E.; Shisa, N.; Hayashi, H.; Saka, S. The effect of monoglyceride polymorphism on cold-flow properties of biodiesel model fuel. J. Am. Oil Chem. Soc. 2017, 94, 1095-1100. [CrossRef]

52. Madihalli, C.; Sudhakar, H.; Doble, M. Mannosylerythritol lipid-a as a pour point depressant for enhancing the low-temperature fluidity of biodiesel and hydrocarbon fuels. Energy Fuels 2016, 30, 4118-4125. [CrossRef]

53. Moser, B.R. Preparation and evaluation of multifunctional branched diesters as fuel property enhancers for biodiesel and petroleum diesel fuels. Energy Fuels 2014, 28, 3262-3270. [CrossRef]

54. Mohanan, A.; Bouzidi, L.; Narine, S.S. Harnessing the synergies between lipid-based crystallization modifiers and a polymer pour point depressant to improve pour point of biodiesel. Energy 2017, 120, 895-906. [CrossRef]

55. Bhale, P.V.; Deshpande, N.V.; Thombre, S.B. Improving the low temperature properties of biodiesel fuel. Renew. Energy 2009, 34, 794-800. [CrossRef]

56. Abe, M.; Hirata, S.; Komatsu, H.; Yamagiwa, K.; Tajima, H. Thermodynamic selection of effective additives to improve the cloud point of biodiesel fuels. Fuel 2016, 171, 94-100. [CrossRef]

57. Yang, F.; Zhao, Y.; Sjoblom, J.; Li, C.; Paso, K.G. Polymeric wax inhibitors and pour point depressants for waxy crude oils: A critical review. J. Dispers. Sci. Technol. 2015, 36, 213-225. [CrossRef]

58. Li, N.; Mao, G.-L.; Shi, X.-Z.; Tian, S.-W.; Liu, Y. Advances in the research of polymeric pour point depressant for waxy crude oil. J. Disp. Sci. Technol. 2017, 39, 1165-1171. [CrossRef] 
59. Ivchenko, P.V.; Nifant'ev, I.E. Polymer depressor additives: Synthesis, microstructure, efficiency. Polym. Sci. Ser. A 2018, 60, 577-593. [CrossRef]

60. Knothe, G. A technical evaluation of biodiesel from vegetable oils vs. algae. Will algae-derived biodiesel perform? Green Chem. 2011, 13, 3048-3065. [CrossRef]

61. Sims, R.E.H.; Mabee, W.; Saddler, J.N.; Taylor, M. An overview of second generation biofuel technologies. Bioresour. Technol. 2010, 101, 1570-1580. [CrossRef] [PubMed]

62. Nautiyal, P.; Subramanian, K.A.; Dastidar, M.G. Production and characterization of biodiesel from algae. Fuel Proc. Technol. 2014, 120, 79-88. [CrossRef]

63. Viêgas, C.V.; Hachemi, I.; Freitas, S.P.; Mäki-Arvela, P.; Aho, A.; Hemming, J.; Smeds, A.; Heinmaa, I.; Fontes, F.B.; da Silva Pereira, D.C.; et al. A route to produce renewable diesel from algae: Synthesis and characterization of biodiesel via in situ transesterification of Chlorella alga and its catalytic deoxygenation to renewable diesel. Fuel 2015, 155, 144-154. [CrossRef]

64. Kligerman, D.C.; Bouwer, E.J. Prospects for biodiesel production from algae-based wastewater treatment in Brazil: A review. Renew. Sustain. Energy Rev. 2015, 52, 1834-1846. [CrossRef]

65. Vassilev, S.V.; Vassileva, C.G. Composition, properties and challenges of algae biomass for biofuel application: An overview. Fuel 2016, 181, 1-33. [CrossRef]

66. Piloto-Rodríguez, R.; Sánchez-Borroto, Y.; Melo-Espinosa, E.A.; Verhelst, S. Assessment of diesel engine performance when fueled with biodiesel from algae and microalgae: An overview. Renew. Sustain. Energy Rev. 2017, 69, 833-842. [CrossRef]

67. Islam, M.A.; Heimann, K.; Brown, R.J. Microalgae biodiesel: Current status and future needs for engine performance and emissions. Renew. Sustain. Energy Rev. 2017, 79, 1160-1170. [CrossRef]

68. Roveda, A.C.; Comin, M.; Caires, A.R.L.; Ferreira, V.S.; Trindade, M.A.G. Thermal stability enhancement of biodiesel induced by a synergistic effect between conventional antioxidants and an alternative additive. Energy 2016, 109, 260-265. [CrossRef]

69. Sajjadi, B.; Raman, A.A.A.; Arandiyan, H. A comprehensive review on properties of edible and non-edible vegetable oil-based biodiesel: Composition, specifications and prediction models. Renew. Sustain. Energy Rev. 2016, 63, 62-92. [CrossRef]

70. De Boer, K.; Bahri, P.A. Supercritical methanol for fatty acid methyl ester production: A review. Biomass Bioenergy 2011, 35, 983-991. [CrossRef]

71. Aransiola, E.F.; Ojumu, T.V.; Oyekola, O.O.; Madzimbamuto, T.F.; Ikhu-Omoregbe, D.I.O. A review of current technology for biodiesel production: State of the art. Biomass Bioenergy 2014, 61, 276-297. [CrossRef]

72. Saka, S.; Kusdiana, D. Biodiesel fuel from rapeseed oil as prepared in supercritical methanol. Fuel 2001, 80, 225-231. [CrossRef]

73. Karki, S.; Sanjel, N.; Poudel, J.; Choi, J.H.; Oh, S.C. Supercritical transesterification of waste vegetable oil: Characteristic comparison of ethanol and methanol as solvents. Appl. Sci. 2017, 7, 632. [CrossRef]

74. Lee, A.F.; Bennett, J.A.; Manayila, J.C.; Wilson, K. Heterogeneous catalysis for sustainable biodiesel production via esterification and transesterification. Chem. Soc. Rev. 2014, 43, 7887-7916. [CrossRef] [PubMed]

75. Lee, A.F.; Wilson, K. Recent developments in heterogeneous catalysis for the sustainable production of biodiesel. Catal. Today 2015, 242, 3-18. [CrossRef]

76. Guldhe, A.; Singh, B.; Mutanda, T.; Permaul, K.; Bux, F. Advances in synthesis of biodiesel via enzyme catalysis: Novel and sustainable approaches. Renew. Sustain. Energy Rev. 2015, 41, 1447-1464. [CrossRef]

77. Knothe, G. Analyzing biodiesel: Standards and other methods. J. Am. Oil. Chem. Soc. 2006, 83, 823-833. [CrossRef]

78. Monteiro, M.R.; Ambrozin, A.R.P.; Lião, L.M.; Ferreira, A.G. Critical review on analytical methods for biodiesel characterization. Talanta 2008, 77, 593-605. [CrossRef]

79. Nimal Ratnayake, W.M.; Hansen, S.L.; Kennedy, M.P. Evaluation of the CP-Sil 88 and SP-2560 GC columns used in the recently approved AOCS official method Ce 1h-05: Determination of cis-, trans-, saturated, monounsaturated, and polyunsaturated fatty acids in vegetable or non-ruminant animal oils and fats by capillary GLC method. J. Am. Oil Chem. Soc. 2006, 83, 475-488. [CrossRef]

80. Pauls, R.E. A review of chromatographic characterization techniques for biodiesel and biodiesel blends. J. Chrom. Sci. 2011, 49, 384-396. [CrossRef] [PubMed]

81. Tariq, M.; Ali, S.; Khali, N. Activity of homogeneous and heterogeneous catalysts, spectroscopic and chromatographic characterization of biodiesel: A review. Renew. Sustain. Energy Rev. 2012, 16, 6303-6316. [CrossRef]

82. Flores, I.S.; Godinho, M.S.; de Oliveira, A.E.; Alcantara, G.B.; Monteiro, M.R.; Menezes, S.M.C.; Lião, L.M. Discrimination of biodiesel blends with ${ }^{1} \mathrm{H}$ NMR spectroscopy and principal component analyses. Fuel 2012, 99, 40-44. [CrossRef]

83. ASTM Updates Biodiesel Specifications for Measuring Cloud Point. Biodiesel Magasine. Available online: http:// biodieselmagazine.com/articles/3420/astm-updates-biodiesel-specifications-for-measuring-cloud-point/ (accessed on 9 May 2021).

84. Santos, N.A.; Rosenhaim, R.; Dantas, M.B.; Bicudo, T.C.; Cavalcanti, E.H.S.; Barro, A.K.; Santos, I.M.G.; Souza, A.G. Rheology and MT-DSC studies of the flow properties of ethyl and methyl babassu biodiesel and blends. J. Therm. Anal. Calorim. 2011, 106, 501-506. [CrossRef]

85. Dunn, R.O. Cold flow properties of biodiesel: A guide to getting an accurate analysis. Biofuels 2015, 6, 115-128. [CrossRef]

86. Chupka, G.M.; Fouts, L.; Lennon, J.A.; Alleman, T.L.; Daniels, D.A.; McCormick, R.L. Saturated monoglyceride effects on low-temperature performance of biodiesel blends. Fuel Proc. Technol. 2014, 118, 302-309. [CrossRef]

87. Chen, W.; Chen, J. Crystallization behaviors of biodiesel in relation to its rheological properties. Fuel 2016, 171, 178-185. [CrossRef] 
88. Alicke, A.A.; Leopércio, B.C.; Marchesini, F.H.; de Souza Mendes, P.R. Guidelines for the rheological characterization of biodiesel. Fuel 2015, 140, 446-452. [CrossRef]

89. Knothe, G.; Dunn, R.O. A comprehensive evaluation of the melting points of fatty acids and esters determined by differential scanning calorimetry. J. Am. Oil Chem. Soc. 2009, 86, 843-856. [CrossRef]

90. Kerschbaum, S.; Rinke, G.; Schubert, K. Winterization of biodiesel by micro process engineering. Fuel 2008, 87, $2590-2597$. [CrossRef]

91. Yuan, M.-H.; Chen, Y.-H.; Chen, J.-H.; Luo, Y.-M. Dependence of cold filter plugging point on saturated fatty acid profile of biodiesel blends derived from different feedstocks. Fuel 2017, 195, 59-68. [CrossRef]

92. Liu, X.; Gibbs, A.S.; Nichol, G.S.; Tang, C.C.; Knight, K.S.; Dowding, P.J.; Mored, I.; Pulham, C.R. Temperature-induced polymorphism in methyl stearate. CrystEngComm 2018, 20, 6885-6893. [CrossRef]

93. Liu, X.; Bull, C.L.; Kleppe, A.K.; Dowding, P.J.; Lewtas, K.; Pulham, C.R. High-pressure crystallisation studies of biodiesel and methyl stearate. CrystEngComm 2019, 21, 4427-4436. [CrossRef]

94. Prathapa, S.J.; Slabbert, C.; Fernandes, M.A.; Lemmerer, A. Structure determination of fatty acid ester biofuels via in situ cryocrystallisation and single crystal X-ray diffraction. CrystEngComm 2018, 21, 41-52. [CrossRef]

95. Lacoste, F.; Dejean, F.; Griffon, H.; Rouquette, C. Quantification of free and esterified steryl glucosides in vegetable oils and biodiesel. Eur. J. Lipid Sci. Technol. 2009, 111, 822-828. [CrossRef]

96. Chupka, G.M.; Yanowitz, J.; Chiu, G.; Alleman, T.L.; McCormick, R.L. Effect of Saturated Monoglyceride Polymorphism on Low-Temperature Performance of Biodiesel. Energy Fuels 2011, 25, 398-405. [CrossRef]

97. Chiu, C.-W.; Schumacher, L.G.; Suppes, G.J. Impact of cold flow improvers on soybean biodiesel blend. Biomass Bioenergy 2004, 27, 485-491. [CrossRef]

98. Wang, J.; Cao, L.; Han, S. Effect of polymeric cold flow improvers on flow properties of biodiesel from waste cooking oil. Fuel 2014, 117, 876-881. [CrossRef]

99. Echim, C.; Maes, J.; De Greyt, W. Improvement of cold filter plugging point of biodiesel from alternative feedstocks. Fuel 2012, 93, 642-648. [CrossRef]

100. Chastek, T.Q. Improving cold flow properties of canola-based biodiesel. Biomass Bioenergy 2011, 35, 600-607. [CrossRef]

101. Chen, W.; Zhao, Z.; Yin, C. The interaction of waxes with pour point depressants. Fuel 2010, 89, 1127-1132. [CrossRef]

102. Xue, Y.; Zhao, Z.; Xu, G.; Lian, X.; Yang, C.; Zhao, W.; Ma, P.; Lin, H.; Han, S. Effect of poly-alpha-olefin pour point depressant on cold flow properties of waste cooking oil biodiesel blends. Fuel 2016, 184, 110-117. [CrossRef]

103. Cao, L.; Wang, J.; Liu, C.; Chen, Y.; Liu, K.; Han, S. Ethylene vinyl acetate copolymer: A bio-based cold flow improver for waste cooking oil derived biodiesel blends. Appl. Energy 2014, 132, 163-167. [CrossRef]

104. Zhou, M.; He, Y.; Lin, H.; Han, S. Effect of MC-MA polymer pour point depressants on the flow properties of biodiesel. Energy Sources Part A Rec. Util. Environ. Eff. 2016, 38, 1962-1968. [CrossRef]

105. Sern, C.H.; May, C.Y.; Zakaria, Z.; Daik, R.; Foon, C.S. The effect of polymers and surfactants on the pour point of palm oil methyl esters. Eur. J. Lipid Sci. Technol. 2007, 109, 440-444. [CrossRef]

106. Boshui, C.; Yuqiu, S.; Jianhua, F.; Jiu, W.; Jiang, W. Effect of cold flow improvers on flow properties of soybean biodiesel. Biomass Bioenergy 2010, 34, 1309-1313. [CrossRef]

107. Muniz, A.S.; Vlnieska, V.; Ferraz, F.A.; dos Santos Oliveira, A.R.; Ramos, L.P.; César-Oliveira, M.A.F. Polymer Additives as Cold Flow Improvers for Palm Oil Methyl Esters. Macromol. Symp. 2019, 383, 1800026. [CrossRef]

108. Nie, S.; Cao, L. Effect of mixed commercial cold flow improvers on flow properties of biodiesel from waste cooking oil. Processes 2020, 8, 1094. [CrossRef]

109. Xue, Y.; Yin, S.; Jin, D.; Zhu, X.; Yang, T.; Yuan, M.; Li, X.; Lin, H.; Han, S. Nitrogen-Containing Ternary Polymer Biodiesel Pour Point Depressant, Preparation Method and Application Thereof. Patent CN111826222, 27 October 2020.

110. Jawak, D.A.; Mitra, P.; Kariparambil, S.K. A Pour Point Depressant Polymer Composition. Patent Application WO2009/047786, 16 April 2009.

111. Lin, H.; Yuan, M.; Yin, S.; Li, X.; Su, B.; Yang, T.; Wu, J.; Xue, Y.; Han, S. Biodiesel Pour Point Depressant Composition as Well as Preparation and Application Thereof. Patent CN111676072, 19 September 2020.

112. Yadav, K.; Kumar, N.; Chaudhary, R. A review on cold flow properties of biodiesel and their improvement. IOP Conf. Ser. Mater. Sci. Eng. 2020, 804, 012027. [CrossRef]

113. Leube, W.; Monkenbusch, M.; Schneiders, D.; Richter, D.; Adamson, D.; Fetters, L.; Dounis, P.; Lovegrove, R. Wax-crystal modification for fuel oils by self-aggregating partially crystallizable hydrocarbon block copolymers. Energy Fuels 2000, 14, 419-430. [CrossRef]

114. Monkenbusch, M.; Schneiders, D.; Richter, D.; Willner, L.; Leube, W.; Fetters, L.J.; Huang, J.S.; Lin, M. Aggregation behaviour of PE-PEP copolymers and the winterization of diesel fuel. Phys. B Condens. Matter 2000, 276-278, 941-943. [CrossRef]

115. Ashbaugh, H.S.; Fetters, L.J.; Adamson, D.H.; Prud'homme, R.K. Flow improvement of waxy oils mediated by self-aggregating partially crystallizable diblock copolymers. J. Rheol. 2002, 46, 763-776. [CrossRef]

116. Schwahn, D.; Richter, D.; Wright, P.J.; Symon, C.; Fetters, L.J.; Lin, M. Self-assembling behavior in decane solution of potential wax crystal nucleators based on poly(co-olefins). Macromolecules 2002, 35, 861-870. [CrossRef]

117. Schwahn, D.; Richter, D.; Lin, M.; Fetters, L.J. Cocrystallization of a poly(ethylene-butene) random copolymer with $C_{24}$ in n-decane. Macromolecules 2002, 35, 3762-3768. [CrossRef] 
118. Guo, X.; Pethica, B.A.; Huang, J.S.; Prud'homme, R.K.; Adamson, D.H.; Fetters, L.J. Crystallization of mixed paraffin from model waxy oils and the influence of micro-crystalline poly(ethylene-butene) random copolymers. Energy Fuels 2004, 18, 930-937. [CrossRef]

119. Guo, X.; Pethica, B.A.; Huang, J.S.; Adamson, D.H.; Prud'homme, R.K. Effect of cooling rate on crystallization of model waxy oils with microcrystalline poly(ethylene butene). Energy Fuels 2006, 20, 250-256. [CrossRef]

120. Tinsley, J.F.; Prud'homme, R.K.; Guo, X.; Adamson, D.H.; Callahan, S.; Amin, D.; Shao, S.; Kriegel, R.M.; Saini, R. Novel laboratory cell for fundamental studies of the effect of polymer additives on wax deposition from model crude oils. Energy Fuels 2007, 21, 1301-1308. [CrossRef]

121. Ilnycky, S.J.; Rupar, C.B. Ethylene-Vinyl Ester Pour Depressant for Middle Distillates. U.S. Patent 3048479,7 August 1962.

122. Chen, J.C. Cold Flow Improver. U.S. Patent 4512775, 23 April 1985.

123. Botros, M.G. Ethylene Vinyl Acetate and Isobutylene Terpolymer as a Cold Flow Improver for Distillate Fuel Compositions. U.S. Patent 5681359, 28 October 1997.

124. Machado, A.L.C.; Lucas, E.F.; Gonzalez, G. Poly(ethylene-co-vinyl acetate) (EVA) as wax inhibitor of a Brazilian crude oil: Oil viscosity, pour point and phase behavior of organic solutions. J. Petrol. Sci. Eng. 2001, 32, 159-165. [CrossRef]

125. Jafari Ansaroudi, H.R.; Vafaie-Sefti, M.; Masoudi, S.; Jafari Behbahani, T.; Jafari, H. Study of the morphology of wax crystals in the presence of ethylene-co-vinyl acetate copolymer. Pet. Sci. Technol. 2013, 31, 643-651. [CrossRef]

126. Mähling, F.-O.; Sondjaja, R.; Hess, B.; Couet, J.; Thong, D. Cold Flow Improver with Broad Applicability in Mineral Diesel, Biodiesel and Blends. U.S. Patent Application 2015344801, 3 December 2015.

127. Hamada, H.; Kato, H.; Ito, N.; Takase, Y.; Nanbu, H.; Mishima, S.; Sakaki, H.; Sato, K. Effects of polyglycerol esters of fatty acids and ethylene-vinyl acetate co-polymer on crystallization behavior of biodiesel. Eur. J. Lipid Sci. Technol. 2010, 112, 1323-1330. [CrossRef]

128. Bartl, H.; Hardt, D. Graft Polymerization of Vinyl Compounds on Ethylene-Vinyl Acetate Copolymers. In Advances in Chemistry; Platzer, N., Ed.; American Chemical Society: Washington, DC, USA, 1969; Volume 91, pp. 477-488. [CrossRef]

129. Liaw, D.-J.; Su, B.-Y. Substantial modifications of ethylene/vinyl acetate copolymers: Saponification and graft copolymerization. Angew. Makromol. Chem. 1993, 212, 77-91. [CrossRef]

130. Ren, Y.; Fang, L.; Chen, Z.; Du, H.; Zhang, X. Synthesis and evaluation of grafted EVAL as pour point depressant for waxy crude oil. Ind. Eng. Chem. Res. 2018, 57, 8612-8619. [CrossRef]

131. Sweeney, W.M. Polyacrylates and Waxy Residual Fuel Compositions Thereof. U.S. Patent US3904385, 9 September 1975.

132. Soldi, R.A.; Oliveira, A.R.S.; Barbosa, R.V.; Cesar-Oliveira, M.A.F. Polymethacrylates: Pour point depressants in diesel oil. Eur. Polym. J. 2007, 43, 3671-3678. [CrossRef]

133. Ma, P.; Xue, Y.; Zhao, W.; Lan, G.; Hang, Z.; Liu, F.; Han, S. Study on the performance mechanism of methacrylate pour point depressant in soybean biodiesel blends. RSC Adv. 2015, 5, 90144-90149. [CrossRef]

134. Xue, Y.; Yang, C.; Xu, G.; Zhao, Z.; Lian, X.; Sheng, H. The influence of polymethyl acrylate as a pour point depressant for biodiesel. Energy Sources Part A Recovery Util. Environ. Eff. 2017, 39, 17-22. [CrossRef]

135. Roy, M.M.; Calder, J.; Wang, W.; Mangad, A.; Diniz, F.C.M. Emission analysis of a modern Tier 4 DI diesel engine fueled by biodiesel-diesel blends with a cold flow improver (Wintron Synergy) at multiple idling conditions. Appl. Energy 2016, 179, 45-54. [CrossRef]

136. Martyak, N.M.; Masy, N.E.; Gernon, M.D.; Schmidt, S.C.; Dowling, C.M. Acrylic Polymer Low Temperature Flow Modifiers in Bio-Derived Fuels. U.S. Patent US8236069, 7 August 2012.

137. Muniz, A.S.; Inoue, M.H.; Oliveira, D.C.; Oliveira, A.R.S.; Ramos, L.P.; Mittelbach, M.; César-Oliveira, M.A.F. Bifunctional additives to improve the cold flow properties and oxidation stability of soybean oil biodiesel. Energy Fuels 2020, 34, 5907-5916. [CrossRef]

138. Lutz, J.-F. Sequence-controlled polymerizations: The next Holy Grail in polymer science? Polym. Chem. 2010, 1, 55-62. [CrossRef]

139. Lappalainen, E.; Koskimies, S. Preparation of alternating olefine maleic anhydride copolymers from C4-C6 hydrocarbon mixtures formed in petrochemical cracking units. J. Polym. Sci. Part C Polym. Lett. 1986, 24, 17-23. [CrossRef]

140. Davis, F.; Hodge, P.; Towns, C.R.; Ali-Adib, Z. Langmuir and Langmuir-Blodgett films of derivatives of alternating copolymers of straight-chain $\alpha$-olefins and maleic anhydride. Macromolecules 1991, 24, 5695-5703. [CrossRef]

141. Martínez, F.; Uribe, E.; Olea, A.F. Copolymerization of maleic anhydride with styrene and $\alpha$-olefins. Molecular and thermal characterization. J. Macromol. Sci. Part A Pure Appl. Chem. 2005, 42, 1063-1072. [CrossRef]

142. Davies, M.C.; Dawkins, J.V.; Hourston, D.J.; Meehan, E. Molar mass determination of poly(octadecene-alt-maleic anhydride) copolymers by size exclusion chromatography and dilute solution viscometry. Polymer 2002, 43, 4311-4314. [CrossRef]

143. Li, L.; Xu, J.; Tinsley, J.; Adamson, D.H.; Pethica, B.A.; Huang, J.S.; Prud'homme, R.K.; Guo, X. Improvement of oil flowability by assembly of comb-type copolymers with paraffin and asphaltene. AIChE J. 2012, 58, 2254-2261. [CrossRef]

144. Mazi, H.; Kibarer, G.; Emregul, E.; Rzaev, Z.M.O. Bioengineering Functional Copolymers. IX. Poly[(maleic anhydride-co-hexene1)-g-poly(ethylene oxide)]. Macromol. Biosci. 2006, 6, 311-321. [CrossRef] [PubMed]

145. Nifant'ev, I.; Vinogradov, A.; Vinogradov, A.; Ivchenko, P. DFT modeling of the alternating radical copolymerization and alder-ene reaction between maleic anhydride and olefins. Polymers 2020, 12, 744. [CrossRef]

146. Soni, H.P.; Kiranbala, A.K.S.; Nagar, A.; Bharambe, D.P. Designing maleic anhydride-a-olifin copolymeric combs as wax crystal growth nucleators. Fuel Proc. Technol. 2010, 91, 997-1004. [CrossRef] 
147. Ke-Jian, L.; Yuchin, Z. A study of three kinds of alkohols esterified copolymer of maleic anhydride and olefins as pour-point depressant for diesels. Pet. Sci. Technol. 1998, 16, 971-977. [CrossRef]

148. Nifant'ev, I.E.; Vinogradov, A.A.; Bondarenko, G.N.; Korchagina, S.A.; Shlyakhtin, A.V.; Roznyatovsky, V.A.; Ivchenko, P.V. Copolymers of maleic anhydride and methylene alkanes: Synthesis, modification, and pour point depressant properties. Polym. Sci. Ser. B 2018, 60, 469-480. [CrossRef]

149. Usta, N.; Aydoğan, B.; Çon, A.H.; Uğuzdoğan, E.; Özkal, S.G. Properties and quality verification of biodiesel produced from tobacco seed oil. Energy Convers. Manag. 2011, 52, 2031-2039. [CrossRef]

150. Li, X.H.; Soriano, N.U.; Bode, H. Cold Flow Additive for Middle Distillate Fuels. Patent Application WO2020014189, 16 January 2020.

151. Tasić, I.; Tomić, M.D.; Aleksić, A.L.J.; Đurišić-Mladenović, N.; Martinović, F.L.; Mićić, R.D. Improvement of low-temperature characteristics of biodiesel by additivation. Hemijska Ind. 2019, 73, 103-114. [CrossRef]

152. Vinogradov, A.A.; Nifant'ev, I.E.; Vinogradov, A.A.; Borisov, R.S.; Ivchenko, P.V. Precision rheological study of the effectiveness of polymer cold flow improvers for corn oil based biodiesel. Mendeleev Commun.. accepted.

153. Tesfaye, M.; Katiyar, V. Microwave assisted synthesis of biodiesel from soybean oil: Effect of poly (lactic acid)-oligomer on cold flow properties, IC engine performance and emission characteristics. Fuel 2016, 170, 107-114. [CrossRef]

154. Abe, M.; Komatsu, H.; Yamagiwa, K.; Tajima, H. Evaluation of the separation of saturated fatty acid methyl esters obtained from additive winterization using a nonionic surfactant. Fuel 2018, 214, 607-613. [CrossRef]

155. Davies, B.W.; Lewtas, K.; Lombardi, A. Oil Additives and Compositions. U.S. Patent US5743923, 28 April 1998.

156. Monirul, I.M.; Kalam, M.A.; Masjuki, H.H.; Zulkifli, N.W.M.; Shahir, S.A.; Mosarof, M.H.; Ruhul, A.M. Influence of poly(methyl acrylate) additive on cold flow properties of coconut biodiesel blends and exhaust gas emissions. Renew. Energy 2017, 101, 702-712. [CrossRef]

157. Monirul, I.M.; Masjuki, H.H.; Kalam, M.A.; Zulkifli, N.W.M.; Shancita, I. Influence of polymethyl acrylate additive on the formation of particulate matter and NOX emission of a biodiesel-diesel-fueled engine. Environ. Sci. Pollut. Res. 2017, 24, 18479-18493. [CrossRef] [PubMed]

158. Islam, M.M.; Hassan, M.H.; Kalam, M.A.; binti Mohd Zulkifli, N.W.; Habibullah, M.; Hossain, M.M. Improvement of cold flow properties of Cocos nucifera and Calophyllum inophyllum biodiesel blends using polymethyl acrylate additive. J. Clean. Product. 2016, 137, 322-329. [CrossRef]

159. Stohr, T.; Schnabel, J.; Janssen, D.; Muller, M. Motor Fuel Composition Comprising Renewable Raw Materials. U.S. Patent Application US2009064568, 12 March 2009.

160. Lin, H.; Xie, M.; Yin, S.; Yang, T.; Su, B.; Chen, F.; Han, S.; Xue, Y. Influence of methacrylate-benzyl methacrylate-N-vinyl-2pyrrolidone as pour point depression on cold flow properties of diesel fuel. Energy Fuels 2020, 34, 1514-1523. [CrossRef]

161. Su, B.; Wang, L.; Xue, Y.; Yan, J.; Dong, Z.; Lin, H.; Han, S. Effect of pour point depressants combined with dispersants on the cold flow properties of biodiesel-diesel blends. J. Am. Oil Chem. Soc. 2021, 98, 163-172. [CrossRef]

162. Lai, Y.; Chen, X.; Yuan, Y. Improving the cold flow properties of biodiesel derived from palm. Adv. Mater. Res. 2011, 236-238, 164-168. [CrossRef]

163. Lv, P.; Cheng, Y.; Yang, L.; Yuan, Z.; Li, H.; Luo, W. Improving the low temperature flow properties of palm oil biodiesel: Addition of cold flow improver. Fuel Proc. Technol. 2013, 110, 61-64. [CrossRef]

164. Shrestha, D.S.; Van Gerpen, J.; Thompson, J. Effectiveness of cold flow additives on various biodiesels, diesel, and their blends. Trans. ASABE 2008, 51, 1365-1370. [CrossRef] 